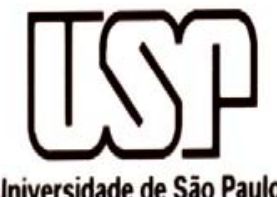

MARIA DEL PILAR VEJARANO RUIBAL

Avaliação de diferentes protocolos de extração de DNA para detecção de Brucella abortus a partir de diferentes tecidos de vacas infectadas experimentalmente com a cepa 2308 


\section{Avaliação de diferentes protocolos de extração de DNA para detecção de Brucella abortus a partir de diferentes tecidos de vacas infectadas experimentalmente com a cepa 2308}

Dissertação apresentada ao Programa de PósGraduação em Epidemiologia Experimental Aplicada às Zoonoses da Faculdade de Medicina Veterinária e Zootecnia da Universidade de São Paulo para obtenção do título de Mestre em Medicina Veterinária

\section{Departamento:}

Medicina Veterinária Preventiva e Saúde Animal

Área de concentração:

Epidemiologia Experimental Aplicada às Zoonoses

Orientador:

Prof. Dr. José Soares Ferreira Neto

São Paulo 
Autorizo a reproduçăo parcial ou total desta obra, para fins acadêmicos, desde que citada a fonte.

DADOS INTERNACIONAIS DE CATALOGAÇÃO-NA-PUBLICAÇĀO

(Biblioteca Virginie Burf D’Áplce da Faculdade de Medicina Veterinătria e Zootecnia da Universidade de Săo Paulo)

T.2134 Vejarano Ruibal, Maria Del Pilar

FMVZ Avaliação de diferentes protocolos de extraçāo de DNA para deteç̧ão de Brucella abortus a partir de diferentes tecidos de vacas infectadas experimentalmente com a cepa 2308 / Maria Del Pilar Vejarano Ruibal. - São Paulo : M. Del P. Vejarano Ruibal, 2009.

$79 \mathrm{f}$ : il.

Dissertação (mestrado) - Universidade de São Paulo. Faculdade de Medicina Veterinária e Zootecnia. Departamento de Medicina Veterinária Preventiva e Saúde Animal, 2009.

Programa de Pós-Graduaçăo: Epidemiologia Experimental Aplicada às Zoonoses.

Área de concentração: Epidemiologia Experimental Aplicada às Zoonoses.

Orientador: Prof. Dr. José Soares Ferreira Neto.

1. B. abortus. 2. Vacas. 3. Extração de DNA. 4. PCR. I. Título. 


\section{CERTIFICADO}

Certificamos que o Projeto intitulado "Avaliação de diferentes protocolos de extração de DNA para detecção de Brucela abortus a partir de diferentes tecidos de vacas infectadas experimentalmente com a cepa 2308", protocolado sob o n¹268/2007, não utilizando animais, sob a responsabilidade do Prof. Dr. José Soares Ferreira Neto, está de acordo com os princípios éticos de experimentação animal da Comissão de Bioética da Faculdade de Medicina Veterinária e Zootecnia da Universidade de São Paulo e foi aprovado na reunião do dia 20 de fevereiro de 2008.

We certify that the Research "Evaluation of different protocols of DNA extraction for Brucella abortus detection from different materials of experimentally infected cows with 2308 strain", protocol number 1268/2007, under the responsibility Prof. Dr. José Soares Ferreira Neto, agree with Ethical Principles in Animal Research adopted by Bioethic Commission of the School of Veterinary Medicine and Animal Science of University of São Paulo was approved in the meeting of day $02 / 20 / 08$.

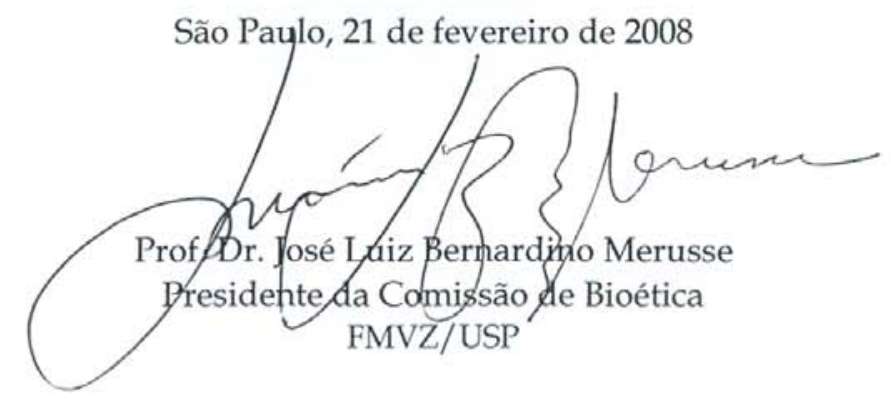




\section{UNIVERSIDADE DE SÃO PAULO \\ Faculdade de Medicina Veterinária e Zootecnia \\ Cidade Universitária "Armando de Salles Oliveira" Comissão Bioética \\ CERTIFICADO}

Certificamos que o Projeto intitulado "Avaliação de vacina contra brucelose bovina não indutora de anticorpos (VNIA)" Protocolo $n^{\circ}$ 296/2003, utilizando 120 bovinos, sob a responsabilidade do Prof. Dr. José Soares Ferreira Neto, está de acordo com os princípios éticos de experimentação animal da Comissão de Bioética da Faculdade de Medicina Veterinária e Zootecnia da Universidade de São Paulo e foi aprovado "ad referendun".

(We certify that the Research "Evaluation of a new vaccine against bovine brucellosis" protocol number 296/2003, utilizing 120 bovines, under the responsibility of Prof. Dr. José Soares Ferreira Neto, agree with Ethical Principles in Animal Research adopted by Bioethic Commission of the Faculty of Veterinary Medicine and Zootechny of University of São Paulo and was approved "ad referendun").

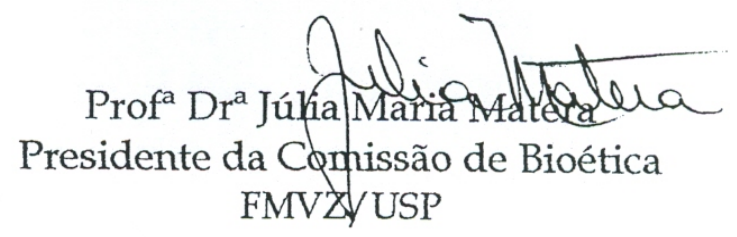




\section{FOLHA DE AVALIAÇÃO}

Nome: VEJARANO RUIBAL, Maria Del Pilar

Título: Avaliação de diferentes protocolos de extração de DNA para detecção de Brucella abortus a partir de diferentes tecidos de vacas infectadas experimentalmente com a cepa 2308

Dissertação apresentada ao Programa de PósGraduação em Epidemiologia Experimental Aplicada às Zoonoses da Faculdade de Medicina Veterinária e Zootecnia da Universidade de São Paulo para obtenção do título de Mestre em Medicina Veterinária

Data:

Banca examinadora

Prof. Dr.

Assinatura:

Prof. Dr.

Assinatura:

Prof. Dr.

Assinatura:
Instituição:

Julgamento:

Instituição:

Julgamento:

Instituição:

Julgamento: 


\section{DEDICATÓRIAS}

Deus, por que sei que tudo o que tenho vem de você. Por estar nas horas mais fracas de minha vida e mostrar-me que sempre tem uma luz na obscuridade.

A minha mãe, ESTELA, Verdadeiro exemplo de luta e dedicação.

Pelo amor, confiança, apoio e conselhos.

Obrigada "Mami".

A Jorge, Compreensão, paciência e amor.

Obrigada por estar sempre comigo.

A mi Mathias, Quem faz que cada dia tenha um novo sentido na minha vida.

Aos meus irmãos, Maria Del Carmen, Quique, Alfredo, Juan e Maria Antonieta, Amigos, confidentes.

Obrigado por seu carinho e seu apoio.

Aos meus sobrinhos, Nishiro, Sayuri, Rodrigo, Adriano, Priscyla, Josue, Nairita, Motivos de muitas alegrias.

A Universidad Nacional Mayor de San Marcos, Por fazer me ver o mundo lá de fora.

À Universidade de São Paulo, Pelo apoio e a oportunidade de enriquecer minha vida acadêmica. 


\section{AGRADECIMENTOS}

Ao Prof. Dr. José Soares Ferreira Neto pela acolhida no Laboratório de Zoonoses Bacterianas, pela confiança no meu trabalho e orientação.

Ao Profs. Paulo Eduardo Brandão pelas sugestões, e amizade oferecida.

Aos Profs. Rodrigo Martins Soares por me ajudarem na realização deste projeto.

A Lara Borges Keid, pela amizade, paciência e vontade de responder sempre todas minhas dúvidas.

A Adriana Cortez, pelo tempo e disponibilidade sempre para ajudar.

Ao César Alejandro Rosales Rodrigues, pelo apoio durante a realização do trabalho.

À Marianna, pela amizade sincera, por ter tempo sempre para me escutar até as bobagens, por fazer minha vida no Brasil inesquecivel, sempre vai ter um lugar especial no meu coração e pela ajuda e conselhos na realização do meu projeto.

A Cassia, pela amizade compartida, por inumeráveis horas de diversão, pela ajuda na realização da minha parte experimental e em todo meu trabalho.

A Lidiane, obrigada pela amizade, pelos conselhos, por fazer de São Paulo um lugar muito mais cálido.

As minhas amigas e colegas do Laboratório de Zoonoses Bacterianas, Vivianne, Flávia Carolina, Wilsilene, Amane, Flávia, Carlos, Ricardo pela amizade, grata convivência, compreensão, e apoio durante toda minha estadia no laboratório, sinceramente muito obrigada.

A Gisele Oliveira de Souza e Zenaide Maria de Morais, pela amizade, conselhos e por estar sempre prestes quando eu precisei. 
Aos estagiários do Laboratório de Zoonoses Bacterianas, pela ajuda na realização da parte experimental de meu projeto.

Ao Laboratório de Ornitopatología, Professor Antonino Piantino, por permitirme desinteresadamente o uso de seus equipamentos, muito obrigada.

Aos meus amigos do Laboratório de Ornitopatologia, tenho que agradecer muita coisa a vocês, Luciana, Liliana, Joelma, Camila, Claudete, e Marcão, obrigada mesmo.

Aos professores e funcionários do VPS, pelos conselhos e por enriquecer minha vida profissional.

A todos os pós-graduandos do VPS, especialmente a Vanessa, Maria, Adriana, Ana Maria, Sibele, Thaisa, Estela, William pela amizade e por os momentos de convivência durante a pós.

Ao LABMAS por estar sempre aberto, por permitir meu aprimoramento nos conhecimentos moleculares.

A Sheila Oliveira de Souza, pela amizade e ajuda na parte experimental de minha tese.

Ao Laboratório de Sanidade Suína Profa. Andréa Moreno e os pós: Renata, Tânia, Sérgio, Débora, e Tais pela amizade, e por estar sempre dispostos a ajudar.

Aos secretários Virgínia, Cristina, Danival e Tânia, por toda a ajuda durante o período da pós.

Às secretárias da pós-graduação da FMVZ-USP Dayse, Claudia e Joana, pelo valioso apoio.

A equipe da biblioteca da FMVZ-USP, pela revisão deste trabalho. 
Aos docentes da Faculdade de Medicina Veterinária e Zootecnia que contribuíram no meu crescimento acadêmico e profissional.

As minhas amigas Elizabeth, Ana María, Kathya, Ursula, Gianina, e Cecilia, pelos anos de amizade, por me apoiarem na minha caminhada e por estar sempre mesmo perante os momentos dificeis.

Ao meu amigo Luis Ll. pela ajuda no depósito de minha tese, muito obrigada.

A todos aqueles que direta ou indiretamente cooperaram na realização deste trabalho.

A FAPESP e à República Federativa do Brasil, pelo auxilio concedido para a realização deste mestrado. 
Creo que más fuerte que la sabiduría, es la imaginación. Que más potente que la historia, es el mito.

Que la esperanza siempre triunfa sobre la experiencia.

Que la única cura para el dolor, es la risa.

Que más poderosos que la realidad, son los sueños.

Robert L. Fulghum 
Le dijo un día un árbol a su retoño

Crece hijo, siempre crece

Proponte alcanzar el cielo.

Fortalece tus raíces,

No temas alejarte del suelo.

Si estas seguro que subes

No te derribarán los vientos

Emula a los que van hacia arriba,

Y a los que están más abajo motiva.

Llénate de hábitos Buenos,

Siembra de amor tu Sendero,

Y ... cuando veas que Dios

Te premió com semillas

Diles esto a tus hijos:

"Crece hijo, siempre crece

Que alcances a ser todo

lo que DIOS planeó para ti

desde que tu semilla

fue seleccionada

para germinar

en la Viña del Mundo"

(Autor desconhecido) 


\section{RESUMO}

VEJARANO RUIBAL, M Del P. Avaliação de diferentes protocolos de extração de DNA para deteç̧ão de Brucella abortus a partir de diferentes tecidos de vacas infectadas experimentalmente com a cepa 2308. [Evaluation of different protocols of DNA extraction for Brucella abortus detection from different tissues from experimentally infected cows with 2308 strain]. 2009. 79 f. Dissertação (Mestrado em Medicina Veterinária) - Faculdade de Medicina Veterinária e Zootecnia, Universidade de São Paulo, São Paulo, 2009.

Este estudo comparou o desempenho de quatro protocolos de extração de DNA a partir de homogeneizados de diferentes órgãos provenientes de vacas infectadas experimentalmente com a B. abortus 2308. Os protocolos de extração comparados foram o método de GT (lise com isotiocianato de guanidina), Boom (lise com GT e tratamento com suspensão carreadora Diatomaceous earth), PK (lise com proteinase K) e Santos (lise por fervura e congelamento com nitrogênio líquido). Foram constituídos os grupos padrão ouro positivo e negativo baseados na bacteriologia clássica e compostos por: 54 cotilédones ( 27 pos. e 27 neg.), 39 linfonodos supra mamários (12 pos. e 27 neg.), 44 pré-escapulares (17 pos. e 27 neg.), 33 fígados (6 pos. e 27 neg.), 37 baços (10 pos. e 27 neg.), e 34 úberes (7 pos. e 27 neg.). Todas as amostras foram submetidas aos quatro protocolos de extração e a um mesmo processo de amplificação com os primers B4 e B5. Nos resultados consolidados por órgãos, a proporção de positivos no cotilédone foi maior do que a encontrada no linfonodo supramamário ( $p=0,0001)$, linfonodo pré-escapular $(p<0,0001)$, fígado $(p=0,0006)$, baço $(p<0,0001)$ ou úbere $(\mathrm{p}=0,0019)$. Os resultados acumulados para os métodos de extração mostraram que o protocolo de Santos teve maior sensibilidade relativa do que o método de Boom $(p=0,003)$ e GT $(p=0,0506)$, e foi igual ao PK $(p=0,2969)$. As demais comparações de proporções não resultaram em diferenças estatisticamente significantes. No estudo verificou-se amostas positivas a PCR e negativas ao isolamento e viceversa. Assim, apesar das desvantagens do método bacteriológico clássico, a melhor estratégia para o diagnóstico direto da infecção de vacas por B. abortus em homogeneizado de órgãos é a utilização conjunta do isolamento e da PCR, examinando os cotilédones e utilizando os métodos de extração de DNA Santos ou PK.

Palavras-chave: B. abortus. Vacas. Extração de DNA. PCR. 


\begin{abstract}
VEJARANO RUIBAL, M Del P. Evaluation of different protocols of DNA extraction for Brucella abortus detection from different tissues from experimentally infected cows with 2308 strain. [Avaliação de diferentes protocolos de extração de DNA para detecção de Brucella abortus a partir de diferentes tecidos de vacas infectadas experimentalmente com a cepa 2308]. 2009. 79 f. Dissertação (Mestrado em Medicina Veterinária) - Faculdade de Medicina Veterinária e Zootecnia, Universidade de São Paulo, São Paulo, 2009.
\end{abstract}

This study compared the performance of four protocols of DNA extraction from suspensions of different tissues from experimentally infected cows with 2308 strain. The compared extraction protocols were GT protocol (lyse with guanidine isotiocianate), Boom (lyse with GT and treated with the carrying suspension Diatomaceous earth), PK (lise with proteinase $\mathrm{K})$ and Santos (lyse by boiling and freezing with liquid nitrogen). Based on classical bacteriology, positive and negative gold standard groups were built and consisted of 54 cotyledons (27 pos. and 27 neg.), 39 supramammary lymph nodes (12 pos. and 27 neg.), 44 prescapulars (17 pos. and 27 neg.), 33 livers (6 pos. and 27 neg.), 37 spleens (10 pos. and 27 neg.), and 34 udders ( 7 pos. and 27 neg.). All the samples were submitted to the four DNA extraction protocols and the same amplification process using the primers B4 and B5. According to consolidated results by tissue, the proportion of positives in cotyledon was bigger than supramammary lymph node $(p=0,0001)$, prescapular lymph node $(p<0,0001)$, liver $(p=0,0006)$, spleen $(p<0,0001)$ and udder $(p=0,0019)$. The consolidated results for the extraction methods show that Santos protocol had bigger relative sensitivity than Boom method $(p=0,003)$ and GT $(p=0,0506)$, and was equal than PK $(p=0,2969)$. There were not significant statistical differences in the others comparisons of proportions. In the study, PCRpositive and isolation-negative samples and vice-versa were verified. However, the disadvantages of the classic bacteriological method, the best strategy for direct diagnosis of the infection of cows for B. abortus in homogenized of tissues is combined use of isolation and PCR, examining the cotyledons and using the methods of DNA extraction from Santos or PK.

Keywords: B. abortus. Cows. DNA extraction. PCR. 


\section{LISTA DE FIGURAS}

Figura 1 -

Figura 2 -

Figura 3 -

Figura 4 -
Gel de agarose mostrando fragmento de $223 \mathrm{pb}$ amplificado pela PCR em amostras de cotilédone de vacas experimentalmente infectadas com Brucella abortus 2308, utilizando extração enzimática do DNA por Proteinase K, onde: (1) padrão de peso molecular, 100 pb; (2-10) amostra de cotilédone; (11-12) controles negativos; (14) padrão de peso molecular, 50 pb - São Paulo - 2009..... 57

Gel de agarose mostrando fragmento de $223 \mathrm{pb}$ amplificado pela PCR em amostras de cotilédone de vacas experimentalmente infectadas com Brucella abortus 2308, utilizando extração enzimática do DNA pelo método adaptado de Boom, onde: (1) padrão de peso molecular, 100 pb; (2-10) amostra de cotilédone; (11-12) controles negativos; (14) padrão de peso molecular, 50 pb - São Paulo - 2009 ..............................................58

Gel de agarose mostrando fragmento de $223 \mathrm{pb}$ amplificado pela PCR em amostras de cotilédone de vacas experimentalmente infectadas com Brucella abortus 2308, utilizando extração enzimática do DNA pelo Isotiocianato de Guanidina - GT, onde: (1) padrão de peso molecular, $100 \mathrm{pb}$; (2-10) amostra de cotilédone; (11-12) controles negativos; (14) água - São Paulo - 2009. .58

Gel de agarose mostrando fragmento de $223 \mathrm{pb}$ amplificado pela PCR em amostras de cotilédone de vacas experimentalmente infectadas com Brucella abortus 2308, utilizando extração enzimática do DNA pelo método adaptado de Santos, onde: (1) padrão de peso molecular, 100 pb; (2-10) amostra de cotilédone; (11-12) controles negativos; (14) água São Paulo - 2009 


\section{LISTA DE QUADROS}

Quadro 1 - $\quad$ Primers utilizados para amplificação do gene codificador da proteína de membrana de 31 kDa da Brucella spp - São Paulo - 2009 49 


\section{LISTA DE TABELAS}

Tabela 1 -

Diluição e volume do DNA extraído utilizados na PCR, segundo o protocolo de extração e o órgão - São Paulo - 2009.

Tabela 2 -

Resultados do isolamento de Brucella abortus 2308 e de sua detecção pela PCR para quatro protocolos de extração de DNA, segundo diferentes concentrações bacterianas - São Paulo - 2009 .53

Tabela 3 -

Resultados da PCR para detecção de Brucella abortus em diferentes órgãos de vacas infectadas experimentalmente com a cepa 2308 realizada com quatro protocolos de extração de DNA, segundo resultados da bacteriologia clássica - São Paulo - 2009........................54

Tabela 4 - $\quad$ Sensibilidade relativa $(\mathrm{Sr})$ para protocolos de extração de DNA utilizados na detecção de Brucella abortus pela PCR em órgãos de vacas experimentalmente infectadas com a cepa 2308, considerando o isolamento pela bacteriologia clássica como gold standard - São Paulo 2009

Tabela 5 - $\quad$ Resultados dos protocolos de extração de DNA para detecção de Brucella abortus pela PCR em órgãos de vacas infectadas experimentalmente com a cepa 2308 - São Paulo - 2009......................56

Tabela 6 - Sensibilidade relativa $(\mathrm{Sr})$ para protocolos de extração de DNA utilizados na detecção de Brucella abortus pela PCR em órgãos de vacas experimentalmente infectadas com a cepa 2308 - São Paulo - 2009.....57

Tabela 7 - $\quad$ Resultados da detecção de Brucella abortus pelo isolamento clássico e pela PCR realizada com quatro diferentes protocolos de extração de DNA em amostras de cotilédone de vacas experimentalmente infectadas como a cepa 2308 - São Paulo - 2009 74

Tabela 8 -

Resultados da detecção de Brucella abortus pelo isolamento clássico e pela PCR realizada com quatro diferentes protocolos de extração de DNA em amostras de linfonodo supramamário de vacas experimentalmente infectadas como a cepa 2308 - São Paulo - 2009...75

Tabela 9 -

Resultados da detecção de Brucella abortus pelo isolamento clássico e pela PCR realizada com quatro diferentes protocolos de extração de DNA em amostras de linfonodo pré-escapular de vacas experimentalmente infectadas como a cepa 2308 - São Paulo - 2009...76

Tabela 10 - $\quad$ Resultados da detecção de Brucella abortus pelo isolamento clássico e pela PCR realizada com quatro diferentes protocolos de extração de DNA em amostras de fígado de vacas experimentalmente infectadas como a cepa 2308 - São Paulo - 2009 
Tabela 11 - $\quad$ Resultados da detecção de Brucella abortus pelo isolamento clássico e pela PCR realizada com quatro diferentes protocolos de extração de DNA em amostras de baço de vacas experimentalmente infectadas como

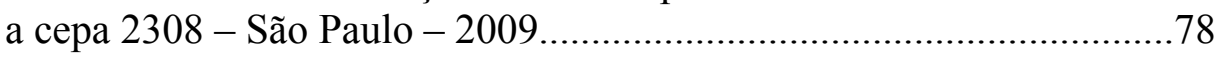

Tabela 12 - $\quad$ Resultados da detecção de Brucella abortus pelo isolamento clássico e pela PCR realizada com quatro diferentes protocolos de extração de DNA em amostras de úbere de vacas experimentalmente infectadas como a cepa 2308 - São Paulo - 2009 79 


\section{LISTA DE ABREVIATURAS}

$$
\begin{aligned}
& \mathrm{cm}=\text { centimetros } \\
& \text { dATP }=\text { desoxi-adenosina trifosfato } \\
& \mathrm{dCTP}=\text { desoxi-citosina trifosfato } \\
& \mathrm{dGTP}=\text { desoxi-guanidina trifosfato } \\
& \mathrm{dNTP}=\text { base nitrogenada }(\mathrm{A}, \mathrm{C}, \mathrm{G} \text { ou } \mathrm{T}) \\
& \text { DNA }=\text { ácido desoxiribonucléico } \\
& \text { dTTP }=\text { desoxi-timidina trifosfato } \\
& \text { EDTA }=\text { ácido etilenodiaminotetracético } \\
& \text { et al. }=\text { e colaboradores } \\
& \mathrm{g}=\text { grama } \\
& \mathrm{g}=\text { gravidade } \\
& \mathrm{HCl}=\text { ácido clorídico } \\
& \mathrm{KDa}=\text { kilodalton } \\
& \mathrm{L}=\text { litro } \\
& \text { LPS }=\text { lipopolissacarídeos } \\
& \mu \mathrm{g} \quad=\text { micrograma } \\
& \mu \mathrm{g} / \mathrm{mL}=\text { micrograma por mililitro } \\
& \mu \mathrm{L}=\text { microlitro } \\
& \mathrm{mg}=\text { miligrama } \\
& \mathrm{MgCl}_{2}=\text { cloreto de magnésio } \\
& \mathrm{mL}=\text { mililitro } \\
& \mathrm{mM}=\text { milimolar } \\
& \mathrm{M} \quad=\operatorname{molar}(\mathrm{mol} \text { por litro) } \\
& \mathrm{N} \quad=\text { normal } \\
& \mathrm{NaCl}=\text { cloreto de sódio } \\
& \text { OIE = Organização internacional de epizootias } \\
& \mathrm{pb}=\text { pares de bases } \\
& \text { PCR = reação em cadeia pela polimerase } \\
& \mathrm{pH}=\text { potencial hidrogeniônico } \\
& \mathrm{PK}=\text { proteinase } \mathrm{K}
\end{aligned}
$$




$$
\begin{array}{ll}
\text { pmol } & \text { picomol } \\
\mathrm{p} / \mathrm{v} & =\text { peso/volume } \\
\mathrm{RNA} & =\text { ácido ribonucléico } \\
\mathrm{rpm} & =\text { rotações por minuto } \\
\mathrm{SDS} & =\text { dodecil sulfato de sódio } \\
\mathrm{Taq} & =\text { Thermus aquaticus } \\
\mathrm{TBE} & =\text { Tris-Borato-EDTA } \\
\mathrm{TE} & =\text { tampão TRIS-EDTA } \\
\mathrm{TRIS} & =\text { Tris (hidroximetil) aminometano } \\
\mathrm{Tris} \mathrm{HCl} & =\text { Tris (hidroximetil) aminometano como ácido clorídico } \\
\mathrm{UFC} & =\text { unidade formadora de colônia } \\
\mathrm{V} & =\text { volts } \\
\mathrm{X} & =\text { vezes }
\end{array}
$$

Nota: Visto terem seu uso consagrado na literatura técnica, algumas abreviaturas seguem as iniciais de sua grafia no idioma inglês. 


\section{LISTA DE SÍMBOLOS}

$\% \quad$ porcentagem

${ }^{\circ} \mathrm{C}$ graus Celsius

$=$ igual

$+\quad$ mais 


\section{SUMÁRIO}

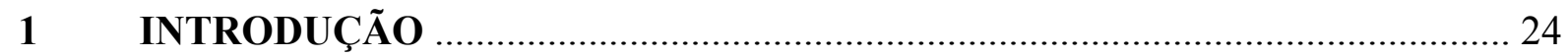

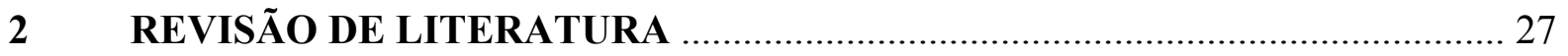

2.1 CARACTERÍSTICAS DO AGENTE ................................................................ 27

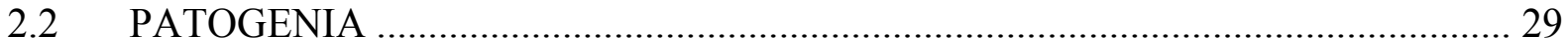

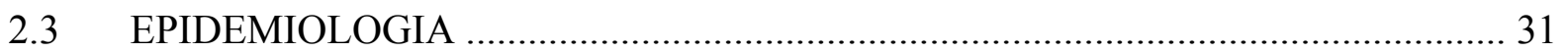

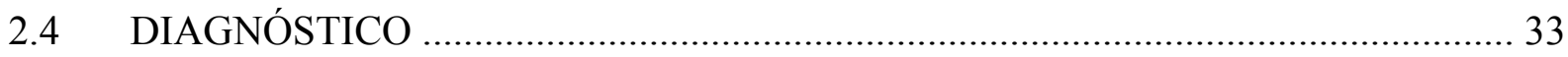

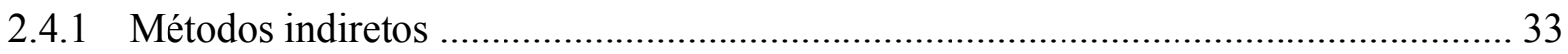

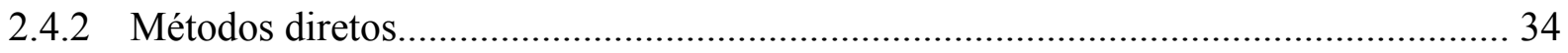

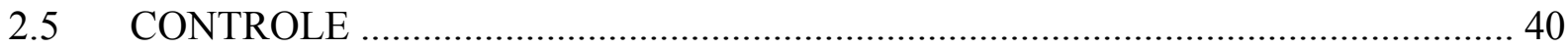

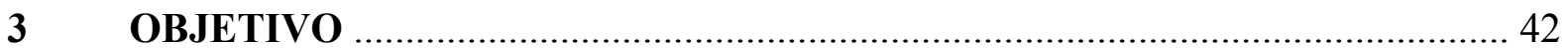

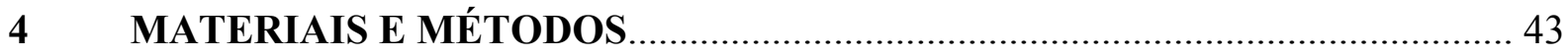

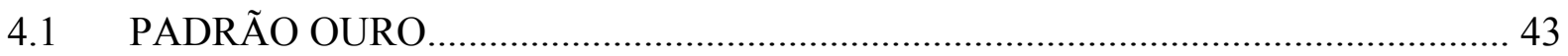

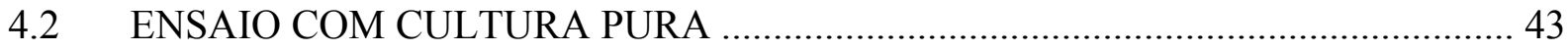

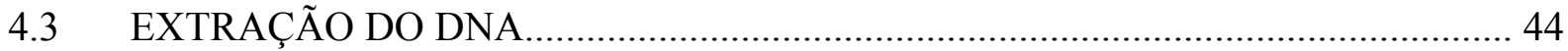

4.3.1 Protocolo 1 - Lise enzimática por Proteinase K e fenol:clorofórmio - PK.................. 44

4.3.2 Protocolo 2 - Lise com isotiocianato de guanidina seguido pelo tratamento com suspensão carreadora (Diatomaceous earth) - Boom ...................................... 45

4.3.3 Protocolo 3 - Lise com isotiocianato de guanidina - GT .......................................47

4.3.4 Protocolo 4 - Lise por fervura e congelamento com nitrogênio líquido - Santos .... 48

4.4 REAÇÃO EM CADEIA PELA POLIMERASE (PCR) ….......................................... 49 
4.4.1 PRIMERS empregados para Brucella spp

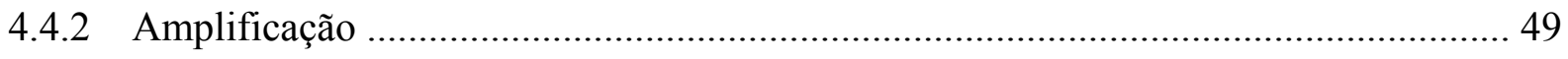

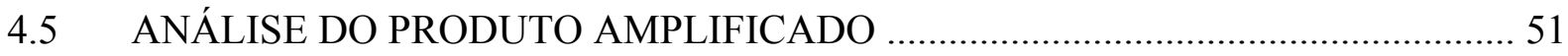

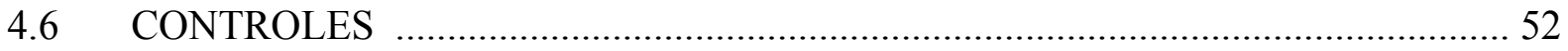

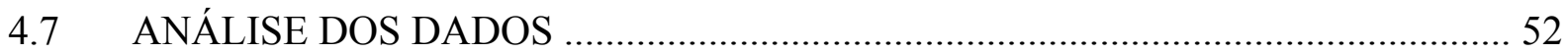

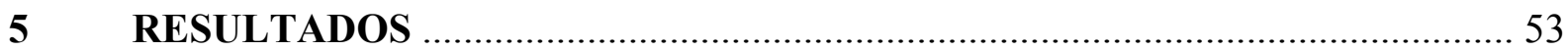

6 DISCUSSÃO

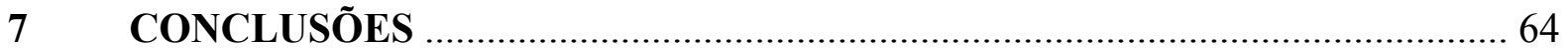

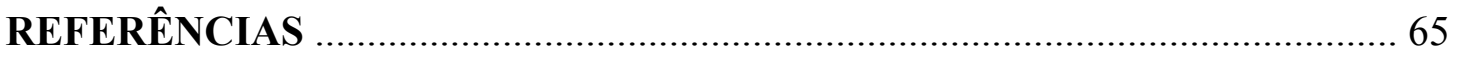

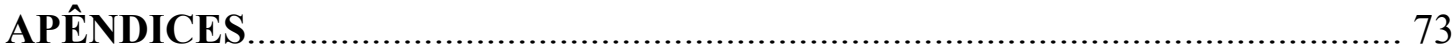




\section{INTRODUÇÃO}

A brucelose é uma zoonose de distribuição mundial que causa diminuição da eficiência reprodutiva e aborto em espécies domésticas e silvestres. Esta doença produz infecção sistêmica que compromete muitos órgãos e tecidos, apresentando sinais inespecíficos (REDKAR et al., 2001). Apesar do estabelecimento de programas de erradicação, a brucelose continua sendo um problema de saúde pública mundial com severas conseqüências econômicas para pecuária (SREEVATSAN et al., 2000).

O agente etiológico da brucelose é uma bactéria facultativa intracelular e gramnegativa, cocobacillus, não formadora de esporos e imóvel, pertencente ao gênero Brucella, classe Proteobacteria (REDKAR et al., 2001; PROBERT et al., 2004). O gênero Brucella é composto por nove espécies (OSTERMAN; MORYIÓN, 2006; FOSTER et al., 2007; SCHOLZ et al., 2008). B. melitensis, B. suis e B. abortus, são espécies lisas, altamente patogênicas e causam doença grave principalmente em caprinos e ovinos, em suínos e em bovinos, respectivamente, assim como no homem (CORBEL et al., 2006). As duas únicas espécies naturalmente rugosas do gênero são B. canis, causadora da brucelose canina e considerada a menos patogênica para o homem, e $B$. ovis, que só foi encontrada infectando naturalmente ovinos (CORBEL, 1997). As espécies B. neotomae e B. microti, isoladas de roedores silvestres, não são consideradas zoonóticas (CORBEL, 1997; SCHOLZ et al., 2008). B. ceti e B. pinnipedialis, patogênicas para mamíferos marinhos (FOSTER et al., 2007), já foram associadas a granulomas intracerebrais em pacientes com neurobrucelose (SOHN et al., 2003), osteomielite da coluna vertebral (MCDONALD et al., 2006) e a acidentes laboratoriais (BREW et al., 1999).

A literatura indica que as espécies de Brucella têm predileção por determinados hospedeiros, não havendo especificidade estrita, como por exemplo, relatos de infecção transmitida por $B$. melitense e $B$. suis. Todas as espécies são consideradas potencialmente patogênicas para os humanos e a transmissão acontece por exposição a animais infectados, carcaças infectadas, pela ingestão de leite ou subprodutos lácteos contaminados e acidentes de trabalho no laboratório (RIJPENS et al., 1996; REDKAR et al., 2001; DAHOUK et al., 2003). A B. ovis e B. neotomae não foram relatadas em humanos (CORBEL, 1997).

As maiores conseqüências econômicas resultam da brucelose bovina causada por $B$. abortus, que leva a restrições internacionais de movimento de animais e comércio de subprodutos (BRICKER; HALLING, 1994; SREEVATSAN et al., 2000). Por tal motivo, os 
programas de erradicação focalizam-se principalmente em B. abortus, e os estudos epidemiológicos precisam contar com técnicas que permitam identificar tanto o gênero e a espécie dos isolados de campo (BRICKER; HALLING, 1994; NEWBY et al., 2003).

No Brasil, a brucelose bovina ocasionada pela B. abortus acarreta grandes perdas econômicas. A situação epidemiológica da doença no país é heterogênea, com prevalências bastante elevadas na região centro-oeste e muito baixas na região sul, sobretudo em Santa Catarina, sul do Paraná e norte do Rio Grande do Sul, que poderiam implementar estratégias de erradicação (Comunicação pessoal) ${ }^{1}$. Poucos estudos têm sido dedicados à investigação dos biovares circulantes entre bovinos no Brasil. No entanto, os poucos existentes têm revelado biovares 1,2 e 3 de $B$. abortus (POESTER et al., 2002).

O diagnóstico da brucelose é feito por métodos diretos e indiretos. Os indiretos são utilizados nas rotinas de certificação de propriedades livres e monitoradas (www.agricultura.gov.br). $\mathrm{O}$ isolamento e identificação bacteriana são baseados nas propriedades morfológicas e bioquímicas de Brucella, e a cultura de sangue e tecidos continua sendo a técnica padrão para o diagnóstico de Brucella spp (EWALT; BRIKER, 2000; OCAMPO-SOSA et al., 2005). Os métodos bacteriológicos clássicos como o isolamento bacteriano e identificação bioquímica e sorológica são custosos, laboriosas, requerem muito tempo, nem sempre oferecem resultados confiáveis e representam um risco para o pessoal do laboratório (REDKAR et al., 2001). Portanto, é preciso contar com técnicas práticas, rápidas e que ofereçam resultados confiáveis que possam ser usadas tanto para fins de diagnóstico quanto para estudos epidemiológicos, como a PCR.

A introdução de técnicas moleculares, notadamente a PCR, representa uma alternativa mais rápida para o diagnóstico de Brucella (PAULIN; FERREIRA NETO, 2003; REDKAR et al., 2001). O diagnóstico direto pode ser feito tanto a partir de feto abortado como rotina de sistema de vigilância, quanto a partir da vaca adulta soropositiva, para confirmar focos bacteriológicos reatores da doença e verificar o andamento do valor preditivo positivo do diagnóstico indireto.

A PCR é altamente sensível e especifica, altamente confiável e reproduzível (MULLIS; FALOONA, 1987). Mas, possui desvantagens que são alto custo e os fatores inibidores da amplificação do ácido nucléico, como proteínas séricas, debris celulares somáticos, polissacarídeos e outros componentes dos fluídos corpóreos (WILSON, 1997). Os fragmentos de órgãos estão sujeitos à ação de inibidores da amplificação do ácido nucléico

\footnotetext{
${ }^{1}$ Informação fornercia por FERREIRA NETO, J. S. em São Paulo, 2009.
} 
(WILSON, 1997). Uma solução para este problema poderia ser a utilização de um protocolo de extração de DNA que diminua o número de falsos negativos, através da eliminação de inibidores da enzima Taq polimerase. 


\subsection{CARACTERÍSTICAS DO AGENTE}

O agente etiológico da brucelose é uma bactéria intracelular facultativa e gram-negativa, cocobacilos curtos e pequenos que medem 0,6 a 1,5 $\mu \mathrm{m}$ por 0,5 a $0,7 \mu \mathrm{m}$ de dimensão, aeróbia, imóvel, não produz cápsula, flagelos ou esporos, pertencente ao gênero Brucella, classe Proteobacteria (REDKAR et al., 2001; WALKER, 2003; PROBERT et al., 2004). Seu crescimento acontece entre $20^{\circ} \mathrm{C}$ e $40^{\circ} \mathrm{C}$, com ótimo crescimento a $37^{\circ} \mathrm{C}$. O pH ideal é 6.6-7.4 (RIEMANN, 2006).

Atualmente se conhecem seis espécies: B. melitensis, B. abortus, B. suis, B. neotomae, $B$. ovis, e B. canis. Esta classificação é principalmente baseada em diferenças de patogenicidade e de hospedeiros (REDKAR et al., 2001; CHU, WEYANT, 2003; CLOECKAERT; VIZCAÍNO, 2004). Recentemente, foram descritas duas espécies em mamíferos marinhos, $B$. pinnipediae e B. cetaceae, (pinnipedos e cetáceos respectivamente) (CLOECKAERT et al., 2001; CLOECKAERT et al., 2003). Hubalek et al. (2007) descobriram uma nova espécie denominada B. microti, procedente de ratazanas selvagens comum (Microtus arvalis) na República Checa.

As Brucellas podem ser divididas em dois grupos antigenicamente distintos: as lisas $(B$. abortus, B. melitensis e B. suis) e as rugosas - B. ovis e B. canis (METCALF et al., 1994). B.

melitensis, B. abortus, e B. suis denominadas como "Brucellas clássicas ou lisas" foram divididas em biotipos, de acordo com diferentes características bioquímicas e/ou comportamentos frente aos soros monoespecíficos A. (abortus) e M. (melitensis) (ACHA; SZYFRES, 2001). As rugosas (B. ovis e B. canis) embora apresentem variantes, não se subdividem em biotipos. Dentro dos biótipos a $B$. melitensis possui os biotipos 1,2 e 3 ; $B$. abortus possui os biotipos 1, 2, 3, 4, 5, 6, 9 e a estirpe vacinal B19; em tanto que e a B. suis apresenta os biovares 1, 2, 3, 4, e 5 (PAULIN; FERREIRA NETO, 2003).

Os antígenos de superfície dominantes estão localizados no lipopolissacarídeo (LPS) que é constituído de três partes: um glicofosfolipídeo denominado lipídio A (LA), endotoxina responsável pela patogenia da doença; um oligossacarídeo central e, em sua porção terminal, a cadeia $\mathrm{O}(\mathrm{CO})$, homopolímero formado por cerca de 100 resíduos do monossacarídeo $\alpha$-D- 
Rhap4Nfo (CORBEL, 1997). A CO é o sitio imunodominante da bactéria, responsável pelo desencadeamento da maior parte da resposta humoral tanto da infecção natural quanto daquela desenvolvida após vacinação pela B19 (SCHURIG, 1997). A CO também se relaciona com a aderência da bactéria às células do hospedeiro, além de lhe conferir resistência aos fagócitos e proteção contra as reações frente a anticorpos e ao sistema de complemento. Devido a essas particularidades, acredita-se que a CO seja importante fator de interação parasita-hospedeiro e que sua ausência resulte em perda da virulência (QUINN et al., 1994).

No ano 1980 foi identificada a maior proteína externa de membrana de Brucella spp. classificada de acordo com sua massa molecular. Verstreate (1982) identificou as proteínas externas de membrana de B. abortus denominas do grupo 2 de $36-38 \mathrm{kDa}$ e a proteína de 25$27 \mathrm{kDa}$ que codificam para o grupo 3. Foram também identificados os genes omp 25 e omp 31. Fitch et al. (1988) identificaram os genes que codificam as proteínas de membrana de $B$. abortus 2308 biovar 1 denominados omp $2 a$ e omp $2 b$ que codificam e expressam a porina de 36-38 kDa. Estes genes compõem 85\% da identidade do DNA. Estudos confirmam que somente o gene omp2b da B. abortus 2308 biovar 1 é codificado e o gene omp2a não é expressado. Os genes mostram diversidade e apresentam marcadores específicos para cada espécie e biovar de Brucella (CLOECKAERT et al., 2002)

As brucelas são moderadamente sensíveis ao calor e à acidez. Quando estão presentes no leite, são destruídas pela pasteurização (JAWETZ, 1984). A capacidade de sobrevivência da Brucella em condições naturais é grande se comparada a de outras bactérias patogênicas não esporuladas, sobretudo em ambiente úmido, ao abrigo da luz solar direta, $\mathrm{pH}$ neutro e em ambiente contendo matéria orgânica (OMS, 1986). Submetida à ação de desinfetantes comuns, como produtos clorados $(2,5 \%$ de cloro ativo), soluções de formaldeídos a $2 \%$ em temperatura ambiente superior a $15^{\circ} \mathrm{C}$, compostos fenólicos a $2.5 \%$ e permanganato de potássio (1:5000), a Brucella é eliminada no máximo em 15 minutos. Álcool 70\% destrói prontamente a bactéria, e carbonato de cálcio (1:10), em 30 minutos (OMS, 1986, SAGDR, 1995). 


\subsection{PATOGENIA}

As brucelas penetram no organismo pela mucosa oral, nasofaríngea, conjuntival ou genital ou pelo contato direto com a pele (ROUX, 1989). A principal porta de entrada para os bovinos é a mucosa orofaringeana (BISHOP et al., 1994). Em seguida, são fagocitadas principalmente pelos macrófagos e carreadas até os linfonodos regionais, onde se multiplicam e podem permanecer por semanas a meses (BATHKE, 1988; BISHOP et al., 1994). Após esta multiplicação inicial, ganham a corrente sangüínea por meio do ducto torácico, dentro dos macrófagos ou livres no plasma (BISHOP et al., 1994). Após a infecção, as células do sistema mononuclear fagocitário, sobretudo macrófagos, ligam-se à Brucella por meio de receptores específicos ou com a ajuda dos anticorpos opsonizantes. A bactéria é interiorizada, digerida e suas frações antigênicas são expostas na superfície celular, permitindo o seu reconhecimento pelos linfócitos $\mathrm{T}$, linfócitos $\mathrm{B}$ e pelas moléculas das classes I do Complexo maior de histocompatibilidade (CMH) (TIZARD, 1996). A partir da circulação, difundem-se para os tecidos do hospedeiro, colonizando, principalmente, órgãos ricos em células do sistema mononuclear fagocitário, como baço, fígado e linfonodos (principalmente os supra mamários), onde podem ocorrer alterações inflamatórias e anatomopatológicas caracterizadas por granulomas difusos, levando à esplenomegalia, hepatomegalia e, às vezes, hiperplasia linfóide (BISHOP et al., 1994).

Os órgãos de predileção são aqueles onde existe maior disponibilidade de elementos necessários para seu metabolismo, como o eritritol (álcool poli-hídrico de quatro carbonos), que está presente no útero gravídico, tecidos mamários e ósteo-articulares e órgãos do sistema reprodutor masculino (CARTER; CHENGAPPA, 1991).

A infecção do útero gestante ocorre por via hematógena. As brucelas multiplicam-se inicialmente no trofoblasto do placentoma, infectando também as células adjacentes, levando a uma reação inflamatória da placenta. Além disso, há infecção do feto, de igual modo por via hematógena. As lesões placentárias raramente atingem todos os placentomas; em geral, apenas parte deles é afetada. Tais lesões inflamatório-necróticas de placentomas, que impedem a passagem de nutrientes e oxigênio da mãe para o feto, assim como provocam a infecção maciça do feto por B. abortus, são as responsáveis pelo aborto. Com o desenvolvimento de imunidade celular após o primeiro aborto, há uma diminuição do número e do tamanho das lesões de placentomas nas gestações subseqüentes. Com isso, o aborto torna-se infreqüente, aparecendo outras manifestações da doença, como por exemplo, a 
retenção de placenta, a natimortalidade ou o nascimento de bezerros fracos (LAGE et al., 2006).

No aparelho reprodutivo masculino, a brucela pode levar à reação inflamatória do tipo necrosante nas vesículas seminais, testículos e epidídimos, com aumento de seu volume uni ou bilateral, provocando sub-fertilidade, infertilidade ou esterilidade. Como seqüela pode haver atrofia do órgão afetado (OMS, 1986).

No aparelho locomotor, causa infecções articulares levando a bursites, principalmente nas articulações carpianas e tarsianas e espondilites, especialmente nas vértebras torácicas e lombares, podendo também atingir medula óssea e bainha dos tendões (BATHKE, 1988; OMS, 1986). Também podem ocorrer osteoartrites, tenosinovites, abortamentos e esterilidade (TIMONEY et al., 1988).

A origem das diversas manifestações clinicas em seres humanos e em animais infetados com Brucella não estão claramente elucidadas. O aumento do número de brucellas no hospedeiro é devido principalmente a sua habilidade de evitar os mecanismos da matança e de proliferar dentro dos macrófagos como outros patógenos intracelulares. Por exemplo, a Brucella não somente resiste à matança por neutrófilos, seguida pela fagocitose, mas, também replica-se dentro de macrófagos e fagócitos não-especializados. Além disto, a sobrevivência nos macrófagos é considerada responsável para o estabelecimento de infecções crônicas permitindo que a bactéria escape dos mecanismos extracelulares de defesa do hospedeiro, tais como o complemento e os anticorpos. Conseqüentemente, para compreender a patogênese da Brucella, os mecanismos que permitem a sobrevivência intracelular deste patógeno têm que ser elucidados (KO; SPLITTER, 2003).

A fonte principal da infecção bovina são os fetos e envolturas fetais, e as descargas vaginais que contêm grande número de brucelas. Em menor grau, podem contribuir com a contaminação do campo, as matérias fecais de bezerros que se alimentam de leite contaminado, já que nem todas as brucelas são destruídas no trato digestivo (ACHA; SZYFRES, 2001). A via de invasão mais freqüente é o trato gastrointestinal, por ingestão de pastos, forragens e água contaminada por brucelas. Além disso, as vacas têm o costume de lamber membranas fetais, fetos e bezerros recém-nascidos, que contêm todos eles grande número de brucelas e constituem uma fonte de infecção muito importante. O hábito das vacas de lamber os órgãos genitais das outras vacas contribui também na transmissão da infecção (ACHA; SZYFRES, 2001).

A susceptibilidade à infecção depende de idade, sexo, raça e estado gestacional. Assim por exemplo, animais mais jovens tendem a ser mais resistentes á infecção e, freqüentemente, 
eliminam infecções, embora elas ocorram na forma latente. Apenas 2.6\% dos animais infectados ao nascimento permanecem infectados quando adultos. De outro lado, animais sexualmente maduros são muito mais suscetíveis à infecção independente do sexo. A maioria dos animais infectados na fase adulta permanecem infectados por toda a vida (WALKER, 2003). O tamanho do rebanho e a densidade animal estão diretamente relacionados á prevalência da doença e dificuldade de controlar a infecção na população. $O$ manejo da parição também desempenha um papel importante na disseminação de brucelose (WALKER, 2003). Em relação ao agente as variáveis incluem dose, virulência, imunogenicidade, patogenicidade e resistência ambiental da estirpe infectante (BISHOP et al., 1994).

No meio ambiente, a existência de rios ou açudes, comumente dividindo lotes de animais de propriedades vizinhas, aumenta o risco da transmissão. Sombreamento, presença de umidade e baixas temperaturas favorecem a sobrevivência do agente no ambiente e, portanto, aumentam as chances dele de entrar em contato e infectar um novo hospedeiro susceptível (PAULIN; FERREIRA NETO, 2003).

$\mathrm{O}$ uso de touros infetados para inseminação artificial constitui um perigo importante, ao difundir a infecção a muitos rebanhos. Em ambientes fechados, é provável que a infecção possa ser transmitida por aerossóis. Também é conhecido o fenômeno de portador latente onde as novilhas serão sorologicamente negativas ou possuirão títulos sorológicos instáveis, soro-convertendo a partir da metade de sua primeira gestação podendo, inclusive, eliminar o agente etiológico (PAULIN; FERREIRA NETO, 2003).

A brucelose no homem é de caráter principalmente profissional, estando mais sujetos à infectar-se as pessoas que trabalham diretamente com os animais infectados ou aqueles que trabalham com produtos de origem animal (DA COSTA et al., 2006).

\subsection{EPIDEMIOLOGIA}

A Brucella abortus foi reconhecida pele primeira vez por Bang em 1897 (CARTER; CHENGAPPA, 1991) e em 1914, Danton Seixas diagnosticou clinicamente pela primeira vez a brucelose bovina no Rio Grande do Sul (PAULIN; FERREIRA NETO, 2003).

A brucelose tem distribuição mundial e causa diminuição da eficiência reprodutiva e aborto em espécies domésticas e silvestres. Esta doença produz infecção sistêmica que compromete muitos órgãos e tecidos, apresentando sinais inespecíficos (REDKAR et al., 
2001). A brucelose é provavelmente a zoonose mais importante nas Américas pelas perdas econômicas que ocasiona e suas repercussões na saúde pública (INPPAZ, 1994). A brucelose continua sendo um grande problema em muitas partes do mundo, particularmente em regiões do Mediterrâneo, ocidente da Ásia, e partes de África e America Latina (CORBEL, 1997). Alguns países no norte e centro de Europa, Canadá, Japão, Austrália e Nova Zelândia se acham estão livres do agente (OIE, 2004).

Bovinos são os hospedeiros preferenciais de B. abortus, mas outros animais, incluindo bisões, camelos e iaques, são comumente infectados. Os diferentes biovares de B. abortus possuem distribuições geográficas distintas. Os biovares 1 e 2 têm distribuição mundial, enquanto o biovar 3 é encontrado predominantemente na Índia, no Egito e na África. O biovar 5 é encontrado mais comumente na Alemanha e no Reino Unido (WALKER, 2003).

No Brasil estudos mostram que a brucelose bovina parece estar disseminada por todo o território brasileiro, com maior ou menor prevalência dependendo da região estudada. $\mathrm{O}$ último diagnóstico de situação da brucelose bovina a nível nacional foi realizado em 1975, sendo estimada a porcentagem de animais soropositivos em 4,0\% na Região Sul, 7,5\% na Região Sudeste, 6,8\% na Região Centro-Oeste, 2,5\% na Região Nordeste e 4,1\% na Região Norte. Posteriormente, outros levantamentos sorológicos por amostragem, realizados em alguns estados, revelaram pequenas alterações na prevalência de brucelose. Os dados de notificações oficiais indicam que a prevalência de animais soropositivos se manteve entre $4 \%$ e 5\%, no período de 1988 a 1998 (LAGE et al., 2006).

Apesar dos poucos estudos realizados visando a identificação das biovariedades de Brucella isoladas de bovídeos no Brasil, já foram identificadas B. abortus biovares 1, 2 e 3 (LAGE et al., 2006).

Existe um risco ocupacional nos veterinários, fazendeiros e magarefes que trabalham com animais infectados e fetos abortados ou restos de placenta (WALKER, 2003; OIE, 2004). Brucelose é uma das infecções mais facilmente adquiridas no laboratório e requer precauções estritas no manejo de culturas e amostras infetadas como produtos de abortos (OIE, 2004). O leite cru ou derivado do leite cru oriundos de bovinos são fontes propícias para infecções em seres humanos (WALKER, 2003). 


\subsection{DIAGNÓSTICO}

A brucelose é diagnosticada por diferentes métodos que se complementam: o diagnóstico clínico baseia-se nos sinais e sintomas; o epidemiológico, no histórico do rebanho da propriedade e complementares diretos e indiretos (PAULIN; FERREIRA NETO, 2003).

\subsubsection{Métodos indiretos}

O sorodiagnóstico é a principal ferramenta para controle da brucelose em rebanhos, pois permite o monitoramento, tanto de propriedades como de regiões. Todos os testes devem ser utilizados respeitando-se as normas técnicas estabelecidas pelos organismos internacionais, com antígenos padronizados e específicos para cada prova (ALTON et al., 1988).

Desde 1897 foram desenvolvidos diferentes testes sorológicos que vêm sendo modificados ao longo do tempo para um melhor desempenho (NIELSEN, 2002). Embora sejam predominantemente direcionados para a pesquisa de anticorpos contra Brucella spp no soro, podem ser detectados em vários fluídos corporais (OIE, 2006).

O Programa Nacional de Controle e Erradicação da Brucelose e Tuberculose (PNCEBT) no Brasil preconiza o Teste do Antígeno Acidificado Tamponado (AAT), que é muito sensível e de fácil execução, e constitui o único teste de triagem, realizado por médicos veterinários habilitados; os animais que reagirem a esse teste poderão ser submetidos a um teste confirmatório, o 2-Mercaptoetanol, que é mais específico, sendo esta prova executada em laboratórios credenciados ou em laboratórios oficiais credenciados; o Teste de Fixação de Complemento (FC), ou outro que o substitua, é realizado em laboratórios oficiais credenciados para efeitos de trânsito internacional e para diagnóstico de casos inconclusivos ao teste do 2-Mercaptoetanol; o Teste do Anel no Leite (TAL) pode ser utilizado para monitoramento da condição sanitária de propriedades certificadas (www.agricultura.gov.br).

Em geral, os testes sorológicos são classificados segundo o antígeno utilizado na reação. Nos testes de aglutinação (lenta, com antígeno acidificado, do anel em leite, de Coombs), de fixação do complemento ou imunofluorescência indireta, o antígeno é representado por células inteiras de B. abortus. Nos testes de imunodifusão em gel (dupla ou radial), Elisa 
(indireto e competitivo), hemólise indireta e Western blot, o antígeno é representado pelo lipopolissacarídeo da parede celular da B. abortus semipurificado (LAGE et al., 2006).

Nenhum teste diagnóstico é capaz de identificar todos os animais infectados e todos os sadios; invariavelmente ocorrerão falso-positivos e falso-negativos. As principais causas de resultados falsos positivos no diagnóstico sorológico da brucelose bovina são reações cruzadas com Escherichia coli O:157, Yersinia enterocolitica O:9, Francisella tularensis, Salmonella urbana O:30, Pseudomonas maltophilia e Vibrio cholera O:1. Essas reações cruzadas estão na maioria das vezes, associadas à IgM (CORBEL, 1985; OMS, 1986). Os anticorpos calostrais são a causa de sorologia positiva em animais de até no máximo quatro meses de idade (BISHOP et al., 1994).

As principais causas de resultados falso-negativos são a infecção recente, o fenômeno prozona e a proximidade como o parto ou aborto (PAULIN; FERREIRA NETO, 2003).

\subsubsection{Métodos diretos}

Os métodos diretos incluem o isolamento e a identificação do agente, a imunohistoquímica, e os métodos de detecção de ácidos nucléicos, principalmente a reação em cadeia da polimerase (PCR) (LAGE et al., 2006).

Os métodos diretos são usados após a manifestação dos sintomas clínicos, quando a bactéria já está disseminada no rebanho. Geralmente são necessários alguns dias até a obtenção do resultado final, são trabalhosos e raramente detectam portadores (BATHKE, 1988). Portanto, não são recomendados para individualizar as fontes de infecção, mas para confirmar focos bacteriológicos da doença e caracterizar o agente circulante. Apesar de ser o método de diagnóstico disponível mais específico para demonstrar a presença da brucela, os resultados negativos não garantem a ausência da infecção (BATHKE, 1988). Na estrutura de um programa, os animais positivos para os métodos indiretos devem ser submetidos ao abate sanitário, durante o qual são colhidas amostras para o diagnóstico direto (PAULIN; FERREIRA, 2003).

Classicamente o diagnóstico direto é realizado a partir do cultivo, isolamento e identificação da Brucella. O material suspeito pode também ser inoculado em animais de laboratório e posteriormente deles isolado (PAULIN; FERREIRA, 2003). O isolamento e a identificação da B. abortus a partir de material de aborto ou de secreções como leite, líquido 
sinovial de articulações comprometidas e sêmen apresentam resultados muito bons se a colheita e o transporte da amostra forem bem realizados e se a amostra for processada em laboratórios capacitados e com experiência (LAGE et al., 2006). No caso de abortamento, recomenda-se a colheita de conteúdo gástrico, baço, rins, pulmão e fígado dos fetos abortados e anexos placentários. Da carcaça de adultos colhem-se linfonodos retrofaríngeos, mandibulares, ilíacos, pré-escapulares e parotídeos, mas principalmente os supramamários, dos quais pode-se isolar Brucella de 90\% dos animais infectados (PAULIN; FERREIRA NETO, 2003). Entretanto, devido ao risco de contaminação humana durante o processamento da amostra, poucos são os laboratórios que realizam este exame (LAGE et al., 2006).

No isolamento inicial, as colônias são observadas de 3 a 5 dias de incubação; em alguns casos é necessária a incubação por até 21 dias. Alguns biovares de B. abortus necessitam de concentração elevada de $\mathrm{CO}_{2}$. Meios enriquecidos com 5\% de soro fetal bovino são exigidos por B. abortus biovar 2 e B. ovis (WALKER, 2003). As colônias de Brucella spp. possuem coloração azuladas características quando examinadas sob luz transmitida obliquamente e medem entre 0.5 a $1.0 \mathrm{~mm}$ de diâmetro (WALKER, 2003; CHU; WEYANT, 2003). São consideradas Gram negativas e coram-se bem pelos métodos de Ziehl-Neelsen e Koster modificados (TIMONEY et al., 1988; CARTER; CHENGAPPA, 1991). À microscopia óptica comum apresentam-se isoladas, aos pares ou em pequenos grupos (METCALF et al., 1994).

As brucelas utilizam carboidratos, mas não produzem nem ácido, nem gás em quantidades suficientes para testes de classificação. Catalase e oxidase são produzidas por algumas cepas. Muitas delas produzem ácido sulfídrico, e reduzem nitratos a nitritos (JAWETZ, 1984). No exame bacteriológico, os materiais suspeitos são semeados em meios de cultura especiais para multiplicação de Brucella, dentre os meios utilizados destacam-se o Ágar Triptose e o ÁgarBrucella (CARTER; CHENGAPPA, 1991).

A identificação das espécies de Brucella pode ser feita através de análise de características fenotípicas, incluindo tipificação sorológica para os antígenos A, M, e R, fenotipagem, provas bioquímicas que identificam diferenças metabólicas entre as espécies e biotipos. As principais provas são: necessidade de $\mathrm{CO}_{2}$, presença de $\mathrm{H}_{2} \mathrm{~S}$, tionina, fucsina básica, aglutinação em soro, tempo de atividade da uréase entre outras (ALTON et al., 1975; METCALF et al., 1994; CLOECKAERT; VIZCAINO, 2004). Uma vantagem deste método direto é a sua especificidade. Porém, como estes microrganismos podem ser disseminados por aerossóis, representa um perigo para o pessoal técnico, além de prolongado tempo para crescimento em cultura (EWALT; BRIKER, 2000; OCAMPO-SOSA et al., 2005). 
A PCR detecta um segmento de DNA específico da B. abortus em material de aborto, em secreções e excreções (LAGE et al., 2006). É uma técnica bastante sensível e específica, econômica, adaptável para trabalhar grandes volumes, confiável e altamente reproduzível em um laboratório equipado apropriadamente (FEKETE et al., 1990; BRICKER, 2002; DAHOUK et al., 2003). A PCR permite trabalhar com a bactéria morta e requer menos tempo que o método convencional ao poder ser automatizado (BRICKER, HALLING, 1994). As principais desvantagens deste método são a presença de fatores inibidores do ácido nucléico, o alto custo de equipamentos e reagentes (PAULIN; FERREIRA, 2003) e requer pessoal treinado (LAGE et al., 2006).

A PCR pode ser utilizada para identificar e diferenciar entre as diferentes espécies e biovares de Brucella e se mostra útil como uma ferramenta epidemiológica e para os programas de erradicação espécie-especificos (BRICKER, 2002).

A sensibilidade da PCR depende da quantidade de DNA presente na amostra e a pureza do DNA; e a especificidade depende do gene e seqüência dos primers escolhidos (FEKETE et al., 1990).

A preparação da amostra é a chave para o sucesso, já que as maiorias destas fontes apresentam ricos inibidores da PCR. Temos que considerar que cada órgão tem inerentes e únicas dificuldades para uma adequada preparação da amostra. O processo comum de extração envolve lise celular para a liberação do DNA bacteriano, mas freqüentemente libera DNA do hospedeiro, limpeza do DNA usualmente pelo fenol e concentração pela precipitação do DNA por álcool, seguida por re-suspensão ou eluição. A maior dificuldade está nos inibidores da PCR e a interferência pelo excessivo DNA do hospedeiro (BRICKER, 2002).

Um ótimo protocolo de extração da amostra teria que cumprir com as seguintes condições: concentrar o DNA, especialmente o derivado do organismo em estudo, limpar os fatores inibidores presentes nos fluidos biológicos, tem que ser aplicável para uso numa rotina diagnóstica, o processo teria que ser adequado para uma ampla variedade de amostras, simples, pelo menos semi-automático, reproduzível, seguro, e teria que prever contaminações cruzadas entre as amostras (RANTAKOKKO-JALAVA; JALAVA, 2002). Existem diferentes substâncias que podem atuar inibindo a amplificação, como hemoglobina, urina, heparina, fenol e dodecil sulfato de sódio (NAVARRO et al., 1999).

Desde 1987 numerosas provas baseadas na PCR para detecção de Brucella foram desenvolvidas e publicadas (BRICKER, 2002). Fekete et al. (1990) apresentaram o primeiro ensaio baseado na reação em cadeia da polimerase para a detecção da Brucella. Baseados nos resultados do ensaio, a seqüência-alvo foi determinada das 25 cepas conhecidas de espécies 
Brucella e seus biovares. A amplificação da seqüência-alvo (um gene que codifica uma proteína externa de membrana de $43-\mathrm{KDa}$ ) não ocorreu com outros 16 patógenos bovinos (3 vírus, 12 bactérias e 1 fungo), nem com o gene bovino. Para esse estudo, os autores observaram sensibilidade de 0,1pg de DNA, ou seja, menos de 100 bactérias. Quando aplicouse o ensaio em abortos e tecido placentário os autores relataram $98 \%$ de sensibilidade e $96 \%$ de especificidade. (FEKETE et al., 1992).

Em 1992, Baily et al. publicaram uma PCR baseada no gene BCSP31, este foi o primeiro loci clonado e seqüenciado (BRICKER, 2004). A PCR de Baily et al. (1992) utilizou um único par de primers oligonucleotideos denominados B4 e B5 para amplificar um segmento de 123 pb que codificam uma seqüência de um gene de $31 \mathrm{kDa}$. Estes primers mostraram uma boa especificidade ao permitir diferenciar à Brucella de outros patógenos Gram negativos. Este ensaio mostrou ser sensível e específico para B. abortus e B. melitensis.

Bricker e Halling (1994) desenvolveram uma PCR para identificar os biovares 1, 2 e 4 de Brucella abortus, os 3 biovares de B. melitensis, o biovar 1 de B. suis e os biovares de B. ovis utilizando o elemento genético IS711 no cromosomo da Brucella em isolados de campo, com uma sensibilidade de $100 \%$.

Uma PCR baseada na seqüência 16S rRNA foi empregada com êxito por Romero et al. (1995). Estes autores testaram amostras clinicas e encontraram que o biotipo D de Ochrobactrum anthropi está estreitamente relacionado com Brucella spp.

Leal-Klevezas et al. (1995) encontraram uma ótima sensibilidade numa PCR que conseguiu diferenciar o biótipo 1 de B. abortus do resto de biótipos de B. abortus em amostras de leite e sangue de animais infectados utilizando um gene que codifica uma proteína externa de membrana (omp 2).

A PCR foi empregada para o diagnóstico de brucelose humana em sangue com $100 \%$ de sensibilidade e $98.3 \%$ de especificidade, este estudo empregou com êxito os primers B4 e B5 descritos por Baily et al. (1992) e Queipo-Ortuño et al. (1997).

Assim também, Gallien et al. (1998) utilizou a PCR para detecção de B. abortus utilizando os primers B4 e B5 em amostras de órgãos de vacas naturalmente infectadas. Neste estudo a PCR conseguiu detectar todas as amostras como positivas, em quanto o isolamento não detectou 5 das amostras positivas.

Çetinkaya et al. (1999) trabalhou como amostras de conteúdo estomacal de fetos bovinos abortados para detecção de Brucella spp comparando a PCR com o cultivo bacteriológico. Eles encontraram que uma amostra foi positiva para PCR e negativa para isolamento, assim como outra amostra deu negativa para PCR e positiva para isolamento. 
Em estudos de Cortez et al. (2001) constataram que entre as 54 amostras consideradas negativas pelo cultivo microbiológico para Brucella spp., a PCR consegui detectar Brucella spp. em 4 delas. Este trabalho sugere que o método de extração de lise por fervura se mostra melhor ao método de PK, pelo pouco tempo na realização e o custo. Neste estudo também empregaram os primers B4 e B5 descritos por Baily et al. (1992).

Richtzenhain et al. (2002) desenvolveram um PCR multiplex para detecção de Leptospira spp. e Brucella spp. em amostras de fetos bovinos abortados. Testaram o método de extração de PK e a lise por fervura. Este ultimo protocolo mostrou melhor resultado em algumas amostras, provavelmente ao fato de remover inibidores da PCR pelo tratamento térmico. Estes autores utilizaram os primers B4 e B5 alcançando uma sensibilidade de 100\% na PCR.

Leyla et al. (2003) usou a PCR baseado no gene IS711 para detecção de Brucella spp. em amostras de conteúdo estomacal de fetos ovinos abortados alcançando uma sensibilidade de 97.4\% e uma especificidade de $100 \%$ quando comparada ao cultivo. Neste estudo empregaram o protocolo de PK como método de extração.

Padilla et al. (2003), evaluaram dois métodos de extração de DNA para detecção de Brucella spp. em cepas peruanas. Estes métodos foram o fenol-clorofórmio-alcool isoamílico e um kit comercial. Estes autores encontraram que ambas metodologias foram eficientes mostrando um alta sensibilidade analítica. Os autores recomendam o uso do kit comercial de extração de DNA devido a sua simplicidade, e o fato de não utilizar reativos corrosivos (como o fenol e clorofórmio) e pela reprodutibilidade de produção de DNA purificado.

Seónadh et al. (2006) realizaram um estudo evaluando o método convencional e um PCR em tempo real para detecção de Brucella abortus em amostras de sangue, leite e linfonodos de vacas naturalmente infectadas. Eles concluíram que pode se isolar B. abortus de amostras de leite e linfonodo. O sangue não se mostrou uma amostra ideal para a detecção deste patógeno. Não se encontro nenhuma vantagem no uso do PCR em tempo real sobre os métodos convencionais sorológicos e bacteriológicos.

Em seqüência, várias técnicas foram empregadas na tentativa de encontrar polimorfismos de DNA as quais possam ser utilizadas na tipificação molecular das espécies de Brucella e seus diferentes biovares. Os genes que codificam as proteínas da membrana externa (OMPs) omp25, omp31, omp2a e omp2b mostram-se úteis para estes propósitos porque eles exibem suficiente polimorfismo que permite diferenciar entre as espécies de Brucella e alguns de seus biovares (FICHT et al., 1990, 1996; CLOECKAERT et al., 1995; VIZCAINO et al., 2000). Estas técnicas incluiram a PCR - Restriction mapping, Pulsed field gel electrophoresis (PFGE), ribotyping, sequenciamento de DNA, PCR Multiplex, AMOS - PCR (B. abortus 


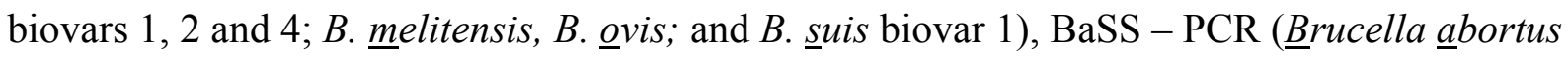
Strain $\underline{S}$ pecific), PCR - RFLP (estriction Fragment Length Polymorphism), AP - PCR

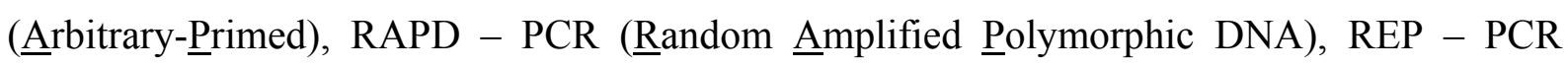
(ㄹepetitive Extragenic Palindromic), ERIC - PCR (Enterobacterial Repetitive Intergenic

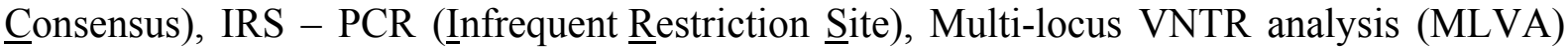
(LÓPEZ-GOÑI; MORIYÓN, 2004).

Uma seqüência inserida chamada de IS6501 (OUAHRANI et al., 1993) ou IS711 (HALLING et al., 1993) foi detectada e muito utilizada para a discriminação das cepas de Brucella ao nível de espécies e intra-espécies (OUAHRANI et al., 1993). O número de cópias de IS6501 no DNA cromossomal varia de 5 até 35, dependendo da espécie de Brucella e pode ser visualizado por hibridação de uma sonda de IS6501 em DNA total de EcoRI-digerida (OUAHRANI et al., 1993). A técnica AMOS-PCR dirigida ao IS711 foi usada com êxito para diferenciar B. abortus biovar 1, 2 e 4; B. melitensis, B. ovis, e B. suis biovar 1 (BRICKER; HALLING, 1994). Outras técnicas moleculares foram desenhadas para a detecção específica das espécies de Brucella utilizando a amplificação de DNA ribossomal localizado entre os genes $r r s-r r$ (RIJPENS et al., 1996).

BaSS-PCR é usado para diferenciar cepas de campo de cepas vacinais de B. abortus (BRICKER et al., 2003; EWALT; BRICKER, 2003). Ficht et al. (1990) usaram Southern hybridisation RFLP do omp $2 a$ e omp $2 b$ para diferenciar as seis espécies de Brucella.

Nas últimas metodologias se encontra o HOOF-Print que é uma técnica simples e rápida para tipagem de B. abortus e útil como metodologia complementar em investigações epidemiológicas em surtos de brucelose localizados. HOOF-Print é uma nova metodologia para a tipagem genotípica de $B$. abortus baseada na hipervariabilidade em tandem presente em 8 loci do genoma, explorando um grau de polimorfismo maior que o até então encontrado no gene, o qual foi observado em regiões genômicas contendo seqüências de DNA curtas, repetidas, em tandem. Os locus com número variável de repetições em tandem (VNTR) sofrem mutações independentes numa taxa individual. Análises VNTR multilocus é efetiva para discriminação de bactérias de difícil tipagem (BRICKER; EWALT, 2005).

Apesar das vantagens aparentes que os métodos baseados na identificação da Brucella por PCR têm sobre os métodos tradicionais de isolamento por cultura, sua aplicação na rotina diagnóstica é bastante limitada pelas seguintes razões: a interpretação dos resultados é, de certa maneira, subjetiva e, na maioria das vezes, requer técnicas complementares para confirmar resultados incertos. Neste caso, os ensaios com a PCR em tempo real (QPCR) tem se mostrado mais rápido e sensível que a PCR convencional. Atualmente, ensaios de QPCR 
SYBR Green têm se mostrado alternativas de baixo custo na execução de exames de triagens em que alta especificidade não seja requerida, entretanto, maiores aprimoramentos as técnicas trarão maior aplicabilidade da metodologia QPCR a rotina diagnóstica de Brucella (COLMENERO et al., 2004).

A possibilidade de uso de técnicas baseadas na detecção de DNA brucélico por meio de PCR se faz bastante útil, principalmente para a identificação de bactérias mortas presentes ou em amostras altamente contaminadas com outros organismos. Entretanto, nenhuma das diversas técnicas de reação em cadeia da polimerase parece ser suficientemente sensível que substitua as técnicas tradicionais de diagnóstico direto por isolamento e identificação, para todos os tipos de amostras biológicas (GARIN-BASTUJI et al., 2006).

\subsection{CONTROLE}

O objetivo das medidas de controle e erradicação é interromper a transmissão da doença com ações especificas dirigidas as fontes de infecção, as vias de transmissão e os animais susceptíveis e medidas inespecíficas aplicadas à movimentação de animais e eventualmente de reservatórios domésticos, sinantrópicos e/ou silvestres (PAULIN; FERREIRA NETO, 2003).

O controle da brucelose bovina é baseado na vacinação das bezerras e na eliminação de portadores. O controle da doença nas outras espécies animais é principalmente através da eliminação de animais com sorologia positiva (DA COSTA, 2006)

Desde a identificação do agente etiológico da brucelose, vários pesquisadores têm procurado desenvolver vacinas que sejam protetoras e que não interfiram no diagnóstico da doença. Em decorrência desses estudos, vêm sendo desenvolvidos grandes números de vacinas vivas atenuadas, mortas, de subunidades, recombinantes e de DNA. Muitas dessas vacinas mostraram-se pouco protetoras, como as vacinas mortas, ou ainda estão em fases de testes, como as vacinas de subunidades, recombinantes e de DNA. As vacinas vivas atenuadas vem sendo utilizadas nos programas de controle da brucelose. Duas delas, recomendadas pela Organização Mundial de Saúde Animal (OIE), são as mais empregadas: a B19 e a vacina não indutora de anticorpos aglutinantes (amostra RB51). Ambas são boas indutoras de imunidade celular (LAGE et al., 2006). 
A vacina de eleição é a $B$. abortus cepa 19, consagrada pelo seu uso universal, pela proteção que confere durante toda a vida útil do animal e pelo seu baixo custo (ACHA; SZYFRES, 2001) foi desenvolvida na década de 30 (ADAMS, 1990). A vacina baseada na cepa viva 19 induz uma razoável proteção, embora, também induza uma excessiva resposta sorológica (SCHURIG et al., 2002). No Brasil, é a vacina obrigatória para bezerras com idade entre 3 e 8 meses. A B19 é atenuada para fêmeas jovens, pode, entretanto, causar orquite nos machos e provocar aborto se administrada durante a gestação. Pode ainda infectar o homem, e dar origem à doença. Portanto, não se recomenda a vacinação de machos ou fêmeas gestantes com a amostra B19 (LAGE et al., 2006).

A vacina não indutora de anticorpos aglutinantes (amostra RB51) é elaborada com uma amostra de $B$. abortus rugosa atenuada, originada da amostra lisa virulenta 2308 que sofreu passagens sucessivas em meio contendo concentrações subinibitórias de rifampicina. Ela possui características de proteção semelhantes às da B19, porém, por ser uma amostra rugosa, não induz a formação de anticorpos anti-LPS liso e não interfere no diagnóstico sorológico da doença. No Brasil, será empregada para a vacinação estratégica de fêmeas adultas (LAGE et al., 2006).

As vacinas baseadas em células mortas de cepas virulentas administradas com adjuvantes induzem uma proteção significativa, mas também produzem níveis inaceitáveis de anticorpos que interferem com os testes diagnósticos (SCHURIG et al., 2002).

Programas de desinfecção e utilização de piquetes de parição são iniciativas simples que trazem como resultado a diminuição da quantidade de brucelas vivas presentes no ambiente. Isso representa diminuir a dose de desafio, o que por sua vez, significa aumentar os índices de proteção da vacina e diminuir a chance da bactéria infectar um novo suscetível (LAGE et al., 2006).

O controle em zonas ou países com baixa prevalência pode se preceder a um programa de erradicação, que consiste principalmente em aplicar ao rebanho repetidos testes sorológicos de diagnóstico, e eliminar os animais reatores até a desaparecimento completo dos focos de infecção (ACHA; SZYFRES, 2001). 


\section{OBJETIVO}

Comparar o desempenho de quatro protocolos de extração de DNA para detecção de Brucella abortus pela PCR a partir de seis órgãos ou estruturas provenientes de vacas infectadas experimentalmente com a B. abortus 2308 . 


\section{MATERIAIS E MÉTODOS}

\subsection{PADRÃO OURO}

Os grupos padrão ouro, tanto positivo quanto negativo, foram compostos por amostras congeladas $\left(-20^{\circ} \mathrm{C}\right)$ de homogeneizados de órgãos, originadas de teste clínico de vacinas realizado no Laboratório de Zoonoses bacterianas da Faculdade de Medicina Veterinária e Zootecnia da Universidade de São Paulo (USP). Todas as amostras utilizadas foram provenientes de vacas desafiadas com B. abortus cepa 2308 por volta do quinto mês de gestação, com uma dose de $3,5 \times 10^{7}$, administrada via ocular, especificamente no saco conjuntival.

O grupo padrão ouro positivo foi composto por 79 amostras positivas para Brucella abortus 2308 pelo isolamento, mediante o método bacteriológico clássico. Este grupo foi composto por 27 amostras de cotilédones, 12 de linfonodos supramamários, 7 de úberes, 17 de linfonodos pré-escapulares, 6 de fígados, e 10 de baços. O grupo padrão ouro negativo foi composto por 27 amostras de cada um desses seis órgãos, das quais não foi possível isolar a B. abortus 2308 .

Todas as amostras foram submetidas a quatro diferentes protocolos de extração de DNA e subseqüentemente ao mesmo método de amplificação e revelação.

\subsection{ENSAIO COM CULTURA PURA}

No ensaio com cultura pura foi utilizada a cepa 2308 de Brucella abortus, cultivada em ágar triptose com adição de 5\% de soro fetal bovino.

Inicialmente foi preparada uma suspensão de brucelas com turvação correspondente ao tubo 0,5 da escala de McFarland (0,5 mL BaCl $2.2 \mathrm{H}_{2} \mathrm{O} 0,048 \mathrm{M}-1,75 \%$ peso/volume in 99,5 $\mathrm{mL} \mathrm{H} \mathrm{H}_{2} \mathrm{SO} 40,36 \mathrm{~N}-1 \%$ volume/volume), a qual corresponde a $1,5 \times 10^{8}$ bactérias $/ \mathrm{mL}$.

A partir dessa suspensão, foram obtidas 18 diluições de razão 10.

Cem microlitros de cada uma dessas diluições foram cultivados em placas com meio 
de Ágar Triptose e após quatro dias foi feita a contagem do número de unidades formadoras de colônias (UFC).

Quatrocentos microlitros de cada uma das diluições foram utilizados para cada um dos protocolos de extração de DNA testados neste experimento.

Todas as amostras extraídas foram submetidas ao mesmo método de amplificação e revelação.

\subsection{EXTRAÇÃO DO DNA}

\subsubsection{Protocolo 1- Lise enzimática por Proteinase K e fenol:clorofórmio - PK (adaptado de LEAL-KLEVEZAS et al., 1995)}

A reação foi realizada em microtubos de $1500 \mu \mathrm{L}$, segundo o seguinte protocolo:

Adicionar $400 \mu \mathrm{L}$ da amostra previamente homogeneizada.

Adicionar $400 \mu \mathrm{L}$ de TE em controles negativos.

Adicionar $1000 \mu \mathrm{L}$ de TE em cada amostra.

Agitar por 10 segundos em vórtex.

Centrifugar a $13000 \mathrm{x} \mathrm{g} / 5$ minutos a $4^{\circ} \mathrm{C}$.

Desprezar o sobrenadante (repetir este procedimento até a suspensão ficar límpida).

Ressuspender o sedimento em $300 \mu \mathrm{L}$ de tampão de lise [10 $\mu \mathrm{L}$ de $\mathrm{Pk} 20$ units/mg, 50 $\mu \mathrm{L}$ de dodecil sulfato de sódio (SDS) a $10 \%, 5 \mu \mathrm{L}$ Tris-HCl 1M, $25 \mu \mathrm{L}$ EDTA 0,5 M, $10 \mu \mathrm{L}$ $\mathrm{NaCl} 5 \mathrm{M}$ e $400 \mu \mathrm{L}$ de água ultrapura].

Incubar em banho-seco a $37^{\circ} \mathrm{C} /$ "overnight" a $600 \mathrm{rpm}$.

Adicionar $500 \mu \mathrm{L}$ de fenol.

Agitar por 20 segundos em vórtex.

Centrifugar a $13000 \mathrm{x} \mathrm{g} / 5$ minutos a $4^{\circ} \mathrm{C}$.

Transferir $300 \mu \mathrm{L}$ da fase aquosa para novo tubo de $1500 \mu \mathrm{L}$, tomando-se cuidado de não aspirar à interface orgânica. 


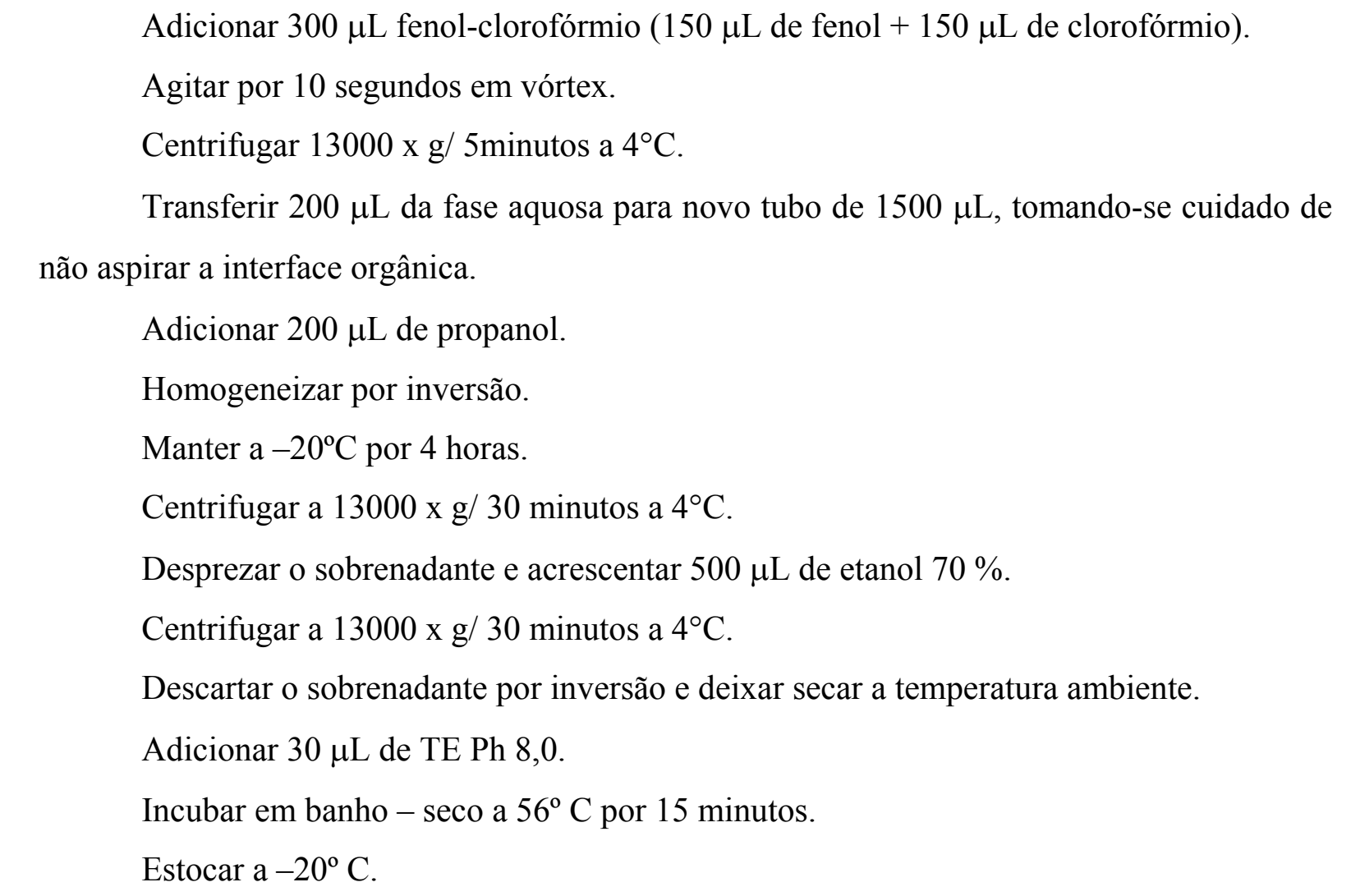

\subsubsection{Protocolo 2- Lise com isotiocianato de guanidina seguido pelo tratamento com suspensão carreadora (Diatomaceous earth). Boom (adaptado de BOOM et al.,1990).}

As amostras foram submetidas ao protocolo adaptado seguindo os seguintes passos:

Transferir $400 \mu \mathrm{L}$ do homogeneizado para um microtubo de $1500 \mu \mathrm{L}$.

Adicionar $1000 \mu \mathrm{L}$ de tampão de lise (120 g GuSCN - 10 mL de 1 M TRIS-HCl Ph 6,4-8,8 mL de EDTA 0,5 M Ph 8,0-1 mL Triton x100).

Acrescentar $40 \mu \mathrm{L}$ da suspensão carreadora (1 g de Diatomaceous earth $-50 \mu \mathrm{L}$ de HCL 37\% - $5 \mathrm{~mL}$ de água ultrapura).

Homogeneizar por 1 minuto em vórtex.

Deixar descansar por 20 minutos.

Centrifugar a $12800 \mathrm{x} \mathrm{g} / 2$ minutos a $4^{\circ} \mathrm{C}$.

Remover o sobrenadante cuidadosamente. 
Adicionar $500 \mu \mathrm{L}$ do tampão de lavagem (120g de GuSCN - 10 mL de 1M TRIS-HCl $\mathrm{Ph}$ 6,4 e $100 \mathrm{~mL}$ de água ultrapura) ao pellet.

Homogeneizar por 1 minuto em vórtex.

Centrifugar a $12800 \mathrm{x} \mathrm{g} / 2$ minutos a $4^{\circ} \mathrm{C}$.

Descartar o sobrenadante.

Adicionar $500 \mu \mathrm{L}$ do tampão de lavagem ao pellet.

Homogeneizar por 1 minuto em vórtex.

Centrifugar a $12800 \mathrm{x} \mathrm{g} / 2$ minutos a $4^{\circ} \mathrm{C}$.

Descartar o sobrenadante.

Adicionar $500 \mu \mathrm{L}$ de etanol 70\%.

Homogeneizar por 1 minuto em vórtex.

Centrifugar a $12800 \mathrm{x} \mathrm{g} / 2$ minutos a $4^{\circ} \mathrm{C}$.

Descartar o sobrenadante.

Adicionar $500 \mu \mathrm{L}$ de etanol 70\%.

Homogeneizar por 1 minuto em vórtex.

Centrifugar a $12800 \mathrm{x} \mathrm{g} / 2$ minutos a $4^{\circ} \mathrm{C}$.

Descartar o sobrenadante.

Adicionar $500 \mu \mathrm{L}$ de acetona.

Homogeneizar por 1 minuto em vórtex.

Centrifugar a $12800 \mathrm{x} \mathrm{g} / 2,5$ minutos a $4^{\circ} \mathrm{C}$.

Descartar o sobrenadante.

Deixar tubo aberto em estufa de $37^{\circ} \mathrm{C} /$ por no mínimo 30 minutos.

Adicionar $150 \mu \mathrm{L}$ de tampão de eluição (1 mL de TRIS-HCl 1M - 0,2 mL de EDTA $\mathrm{Ph}$ 8,0 e 98,8 mL de água ultrapura).

Agitar por 1 minuto em vórtex.

Incubar em banho seco à $55^{\circ} \mathrm{C} / 10$ minutos.

Agitar por 1 minuto em vórtex.

Centrifugar a $12800 \mathrm{x} \mathrm{g} / 5$ minutos a $4^{\circ} \mathrm{C}$.

Transferir $70 \mu \mathrm{L}$ da fase aquosa para novo tubo de $1500 \mu \mathrm{L}$ tomando-se cuidado de não aspirar a interface orgânica.

Centrifugar a $12800 \mathrm{x} \mathrm{g} / 5$ minutos a $4^{\circ} \mathrm{C}$.

Estocar a temperatura de $-20^{\circ} \mathrm{C}$. 


\subsubsection{Protocolo 3- Lise com isotiocianato de guanidina - GT (adaptado de CHOMKZYNSKI, 1993)}

Colocar $400 \mu \mathrm{L}$ amostra $+900 \mu \mathrm{Lde}$ GT $(60 \mathrm{~g}$ de isotiocianato de guanidina $+5 \mathrm{~mL}$ de TRIS-HCl 1M Ph 7,5 + $10 \mathrm{~mL}$ de EDTA 0,25 M Ph 8,0 + $100 \mathrm{~mL}$ de fenol $+\mathrm{ddH}_{2} \mathrm{O}$ qsp 100 $\mathrm{mL}$ ) em um novo microtubo de $1500 \mu \mathrm{L}$.

Vórtex 15 segundos e aguardar 10 minutos com novo vórtex ao final e fazer spin.

Acrescentar $200 \mu \mathrm{L}$ clorofórmio, vórtex 15 segundos e descansar 10 minutos.

Centrifugar $12000 \mathrm{x} \mathrm{g} / 5$ minutos a $4^{\circ} \mathrm{C}$.

Recuperar o sobrenadante $(700 \mu \mathrm{L})$ e adicionar igual volume de propanol (700 $\mu \mathrm{L}-$ para insolubilizar o DNA)- homogeneizar manualmente.

Congelar $\mathrm{a}-20^{\circ} \mathrm{C}$ por 2 horas.

Centrifugar $12000 \mathrm{xg} / 20$ minutos a $4^{\circ} \mathrm{C}$.

Desprezar o material com cuidado.

Colocar $500 \mu \mathrm{L}$ etanol 70\% e homogeneizar manualmente.

Centrifugar $12000 \mathrm{xg} / 10$ minutos a $4^{\circ} \mathrm{C}$.

Desprezar o sobrenadante e deixar secar em temperatura ambiente sobre um papel toalha.

Adicionar $30 \mu \mathrm{L}$ de $\mathrm{TE}$, vórtex e spin rápido.

Banho seco $56^{\circ} \mathrm{C}$ por 15 minutos.

Acondicionar em freezer $-20^{\circ} \mathrm{C}$. 


\subsubsection{Protocolo 4- Lise por fervura e congelamento com nitrogênio líquido (adaptado de SANTOS, 1995)}

Transferir $400 \mathrm{~mL}$ do homogeneizado para um microtubo de $1500 \mu \mathrm{L}$.

Centrifugar a $14000 \mathrm{x} \mathrm{g} / 5$ minutos a $4^{\circ} \mathrm{C}$ e desprezar o sobrenadante.

Adicionar $50 \mu \mathrm{L}$ de $\mathrm{NaOH}$ a $0,5 \mathrm{M}$ e manter sobre leve agitação/ 10 minutos.

Adicionar $25 \mu \mathrm{L}$ de $\mathrm{NaH}_{2} \mathrm{PO}_{4}$ a $1 \mathrm{M}$.

Centrifugar a $14000 \mathrm{x} \mathrm{g} / 10$ minutos a $4^{\circ} \mathrm{C}$.

Desprezar sobrenadante.

Adicionar $50 \mu \mathrm{L}$ de TE 1\% Triton X - 100 .

Ferver em um heat block por 10 minutos e centrifugar por 15 segundos.

Congelar em $\mathrm{N}_{2}$ líquido por 5 minutos e centrifugar por 15 segundos.

Repetir duas vezes a fervura e o congelamento.

Adicionar $150 \mu \mathrm{L}$ de fenol.

Agitar por 20 segundos em vórtex e centrifugar a 14000 x g/5 minutos a $4^{\circ} \mathrm{C}$.

Transferir $100 \mu \mathrm{L}$ da fase aquosa para novo tubo de $1500 \mu \mathrm{L}$, tomando-se cuidado de não aspirar a interface orgânica.

Adicionar $200 \mu \mathrm{L}$ fenol-clorofórmio-álcool isoamílico, na proporção de 25:24:1.

Agitar por 10 segundos em vórtex e centrifugar $14000 \mathrm{x} \mathrm{g} / 5$ minutos a $4^{\circ} \mathrm{C}$.

Transferir $75 \mu \mathrm{L}$ da fase aquosa para novo tubo de $1500 \mu \mathrm{L}$, tomando-se cuidado de não aspirar a interface orgânica.

Adicionar $75 \mu \mathrm{L}$ de propanol e homogeneizar por inversão.

Manter a $-20^{\circ} \mathrm{C}$ por 4 horas e centrifugar a $14000 \mathrm{x} \mathrm{g} / 10$ minutos a $4^{\circ} \mathrm{C}$.

Descartar o sobrenadante por inversão.

Adicionar $400 \mu \mathrm{L}$ etanol 70\%.

Centrifugar a $14000 \mathrm{x}$ g/ 10 minutos a $4^{\circ} \mathrm{C}$.

Descartar o sobrenadante por inversão e deixar secar a temperatura ambiente.

Adicionar $30 \mu \mathrm{L}$ de TE $\mathrm{Ph} 8,0$ e incubar em banho seco a $56^{\circ} \mathrm{C} / 15$ minutos.

Estocar a $-20^{\circ} \mathrm{C}$. 


\subsection{REAÇÃO EM CADEIA PELA POLIMERASE (PCR)}

\subsubsection{PRIMERS empregados para Brucella spp.}

Para a amplificação do DNA, foi utilizado o par de primers $\mathrm{B}_{4}$ e $\mathrm{B}_{5}$ (Quadro 1), descrito por Baily et al. (1992), que amplificam um fragmento de $223 \mathrm{pb}$.

\begin{tabular}{|c|c|c|}
\hline Primers & Seqüência & Amplicon \\
\hline $\mathrm{B}_{4}$ & 5' TGGCTCGGTTGCCAATATCAA 3' $^{\prime}$ & $223 \mathrm{bp}$ \\
$\mathrm{B}_{5}$ & 3' CGCGCTTGCCTTTCAGGTCTG 5' & \\
\hline
\end{tabular}

Quadro 1- $\quad$ Primers utilizados para amplificação do gene codificador da proteína de membrana de $31 \mathrm{kDa}$ da Brucella spp - São Paulo - 2009

\subsubsection{Amplificação}

Para cada protocolo de extração ensaiado, a quantidade de DNA extraído utilizada na PCR foi estipulada em teste com diferentes diluições. Foi escolhida a diluição onde foi obtido um maior numero de amostras positivas. A tabela 1 mostra os resultados desse teste. 
Tabela 1- Diluição e volume do DNA extraído utilizados na PCR, segundo o protocolo de extração e o órgão - São Paulo - 2009

\begin{tabular}{|c|c|c|c|}
\hline $\begin{array}{r}\text { Protocolo de } \\
\text { extração } \\
\text { de DNA }\end{array}$ & Órgão & $\begin{array}{r}\text { Diluição do DNA extraído } \\
\text { utilizada na PCR }\end{array}$ & $\begin{array}{r}\text { Volume da diluição de DNA } \\
\text { extraído utilizado na } \\
\text { PCR }\end{array}$ \\
\hline \multirow{6}{*}{ PK } & Cotilédone & $1: 3$ & $5 \mathrm{uL}$ \\
\hline & Linfonodo supramamário & $1: 3$ & $5 \mathrm{uL}$ \\
\hline & Linfonodo pré-escapular & $1: 3$ & $5 \mathrm{uL}$ \\
\hline & Fígado & $1: 3$ & $5 \mathrm{uL}$ \\
\hline & Baço & $1: 10$ & $5 \mathrm{uL}$ \\
\hline & Úbere & $1: 3$ & $5 \mathrm{uL}$ \\
\hline \multirow{6}{*}{ Boom } & Cotilédone & sem diluição & $5 \mathrm{uL}$ \\
\hline & Linfonodo supramamário & sem diluição & 10ul \\
\hline & Linfonodo pré-escapular & sem diluição & 10ul \\
\hline & Fígado & $1: 2$ & $5 \mathrm{uL}$ \\
\hline & Baço & sem diluição & $5 \mathrm{uL}$ \\
\hline & Úbere & sem diluição & 10ul \\
\hline \multirow{6}{*}{ GT } & Cotilédone & $1: 4$ & $5 \mathrm{uL}$ \\
\hline & Linfonodo supramamário & $1: 15$ & $5 \mathrm{uL}$ \\
\hline & Linfonodo pré-escapular & $1: 15$ & $5 \mathrm{uL}$ \\
\hline & Fígado & $1: 2$ & $5 \mathrm{uL}$ \\
\hline & Baço & $1: 10$ & $5 \mathrm{uL}$ \\
\hline & Úbere & $1: 4$ & $5 \mathrm{uL}$ \\
\hline \multirow{6}{*}{ Santos } & Cotilédone & $1: 2$ & $5 u L$ \\
\hline & Linfonodo supramamário & $1: 12$ & $5 \mathrm{uL}$ \\
\hline & Linfonodo pré-escapular & $1: 10$ & $5 \mathrm{uL}$ \\
\hline & Fígado & $1: 12$ & $5 \mathrm{uL}$ \\
\hline & Baço & $1: 5$ & $5 \mathrm{uL}$ \\
\hline & Úbere & 1:5 & $5 \mathrm{uL}$ \\
\hline
\end{tabular}

A amplificação do DNA da bactéria Brucella abortus foi realizada em microtubos de 200 $\mu \mathrm{L}$, de acordo com o protocolo de Cortez et al. (2001).

Os reagentes utilizados foram:

- $20 \mu \mathrm{L}$ de água ultrapura obtida em aparelho Milli-Q-Millipore Inc. (Billerica, MA, USA) 
- $5 \mu \mathrm{L}$ de tampão de reação 10 X $\left(500 \mathrm{mM} \mathrm{KCL}, 15 \mathrm{nM} \mathrm{MgCl}_{2}, 100 \mathrm{mM}\right.$ Tris- HCl, pH $9,0)$

- 8,0 $\mu \mathrm{L}$ da mistura de dNTPs $(200 \mu \mathrm{M}$ de cada nucleotídeo [dCTP, dATP, dGTP, dTTP])

- $\quad 1,5 \mu \mathrm{L}$ de $\mathrm{MgCl}_{2}(50 \mathrm{mM})$

- $5 \mu \mathrm{L}$ do primer $\mathrm{B}_{4}(10 \mathrm{pmol} / \mu \mathrm{L})$

- $\quad 5 \mu \mathrm{L}$ do primer $\mathrm{B}_{5}(10 \mathrm{pmol} / \mu \mathrm{L})$

- $\quad 0,5 \mu \mathrm{L}$ de $\operatorname{Taq}$ DNA polimerase ( 5 unidades por $\mu \mathrm{L}$ ).

- $5 \mu \mathrm{L}$ da amostra.

O volume final da solução para a amplificação consistiu de $50 \mu \mathrm{L}$, sendo $5 \mu \mathrm{L}$ de amostra e $45 \mu \mathrm{L}$ de mix; com exceção das amostras de linfonodo supramamário, linfonodo préescapular, úbere e baço no protocolo de Boom, onde se empregou $10 \mu \mathrm{L}$ de amostra e $40 \mu \mathrm{L}$ de mix.

Para as amplificações foi adotado o seguinte ciclo, descrito por BAILY et al. (1992):

* Desnaturação inicial: $94^{\circ} \mathrm{C}$ por 5 minutos

Foram empregados 40 ciclos, divididos como descrito abaixo:

* Desnaturação do DNA: $94^{\circ} \mathrm{C}$ por 1 minuto - repetir 40 vezes

- Hibridização: $60^{\circ} \mathrm{C}$ por 1 minuto - repetir 40 vezes

* Extensão: $72^{\circ} \mathrm{C}$ por 1 minuto - repetir 40 vezes

* Extensão final: $72^{\circ} \mathrm{C}$ por 10 minutos

\subsection{ANÁLISE DO PRODUTO AMPLIFICADO}

A visualização do produto amplificado $(10 \mu \mathrm{l})$ foi realizada através da técnica de eletroforese em uma cuba horizontal com tampão de corrida TBE $0,5 \mathrm{X}$ (0,045 M Tris-borato e 1 mM EDTA, pH 8,0), em 1.5\% de agarose (p/v). O gel foi submetido à voltagem constante de $6-7 \mathrm{~V} / \mathrm{cm}$.

A visualização das bandas foi realizada com a imersão do gel numa solução de brometo de etídio a $0,5 \mu \mathrm{g} / \mathrm{mL}$ durante 20 minutos e posterior observação em transiluminador 
ultravioleta (SAMBROOK et al., 1989).

As bandas foram comparadas com o padrão de peso molecular (Invitrogen ${ }^{\circledR}$ ) que possuía fragmentos múltiplos de 100 pares de bases disposto no gel juntamente com as amostras analisadas, a cada corrida eletroforética.

O gel foi fotografado através do sistema FCR-10 câmera/Fotodyne, com filme Polaroid 667 ASA 3000.

\subsection{CONTROLES}

Foram tomadas precauções para evitar a contaminação de utensílios e equipamentos de laboratório com material genético (DIEFFENBACH et al., 1995), diminuindo-se dessa forma o risco de falsos positivos, bem como falhas na reação. Para cada dez amostras processadas, foram inserido duas amostras contendo TE, as quais serviram como controle negativo.

\subsection{ANÁLISE DOS DADOS}

Para cada um dos protocolos foram calculados os valores da sensibilidade relativa e seus intervalos de confiança considerando o isolamento ou infecção experimental como gold standard. As comparações das proporções foram feitas pelo teste qui-quadrado. Os cálculos foram realizados com o auxílio dos programas Epi Info 6.0 e Med Calc 8.2. 


\section{RESULTADOS}

A tabela 2 apresenta os resultados dos ensaios com culturas puras de B. abortus 2308 , mostrando o limiar de deteç̧ão do isolamento pelo método bacteriológico clássico e das PCR realizadas com quatro diferentes métodos de extração de DNA.

Tabela 2- $\quad$ Resultados do isolamento de Brucella abortus 2308 e de sua detecção pela PCR para quatro protocolos de extração de DNA, segundo diferentes concentrações bacterianas - São Paulo - 2009

\begin{tabular}{c|ccccc}
\hline \multirow{2}{*}{$\begin{array}{c}\text { Número de } \\
\text { bactérias } / \mathbf{m L}^{*}\end{array}$} & $\begin{array}{c}\text { Isolamento } \\
\text { Brucella abortus }\end{array}$ & \multicolumn{5}{c}{ PK } & BOOM & GT & SANTOS \\
\hline $10^{8}$ & + & + & + & + & + \\
$10^{7}$ & + & + & + & + & + \\
$10^{6}$ & + & + & + & + & + \\
$10^{5}$ & + & + & + & + & + \\
$10^{4}$ & + & + & + & + & + \\
$10^{3}$ & + & + & + & + & + \\
$10^{2}$ & + & - & - & + & - \\
$10^{1}$ & + & - & - & + & - \\
$10^{0}$ & + & - & - & + & - \\
$10^{-1}$ & - & - & - & + & - \\
$10^{-2}$ & - & - & - & + & - \\
$10^{-3}$ & - & - & - & - & - \\
$10^{-4}$ & - & - & - & - & - \\
$10^{-5}$ & - & - & - & - & - \\
$10^{-6}$ & - & - & - & - & - \\
$10^{-7}$ & - & - & - & - & - \\
$10^{-8}$ & - & - & - & - & - \\
$10^{-9}$ & - & - & - & - & - \\
$10^{-10}$ & - & - & - & - \\
\hline
\end{tabular}

* Suspensão de colônias de Brucella abortus com turvação correspondente ao tubo 0,5 da escala de Mc Farland $\left(1,5 \times 10^{8}\right.$ bactérias $\left./ \mathrm{mL}\right)$ e a partir desta foram feitas diluições de razão 10.

As amostras entre $1,5 \times 10^{8}$ a $1,5 \times 10^{4}$ bactérias $/ \mathrm{mL}$ apresentaram incontável número de unidades formadoras de colônia (UFC) nos cultivos quantitativos e as amostras com 1,5 $\mathrm{x}$ $10^{3}, 1,5 \times 10^{2}, 1,5 \times 10^{1}$ e $1,5 \times 10^{0}$ bactérias $/ \mathrm{mL}$ apresentaram $430,56,4$ e 2 UFC/mL. As amostras de $1,5 \times 10^{-1}$ até $1,5 \times 10^{-10}$ bactérias/mL não apresentaram crescimento. 
A Tabela 3 mostra os resultados da PCR para detecção de B. abortus, executada com quatro diferentes métodos de extração de DNA em órgãos de vacas infectadas experimentalmente com a cepa 2308, segundo resultados da bacteriologia clássica. A Tabela 4 traz os valores de sensibilidade relativa verificada para cada método de extração de DNA segundo os órgãos examinados, tendo como gold standard os resultados do isolamento pela bacteriologia clássica. As duas tabelas apresentam resultados acumulados por protocolo de extração e órgãos.

Tabela 3 - Resultados da PCR para detecção de Brucella abortus em diferentes órgãos de vacas infectadas experimentalmente com a cepa 2308 realizada com quatro protocolos de extração de DNA, segundo resultados da bacteriologia clássica - São Paulo - 2009

\begin{tabular}{|c|c|c|c|c|c|c|c|c|c|c|c|c|c|c|c|}
\hline \multirow{3}{*}{$\begin{array}{l}\text { Resultado do } \\
\text { isolamento } \\
\text { nos órgãos }\end{array}$} & \multicolumn{15}{|c|}{ Resultados da PCR segundo os protocolos de extração de DNA } \\
\hline & \multicolumn{3}{|c|}{ PK } & \multicolumn{3}{|c|}{ BOOM } & \multicolumn{3}{|c|}{ GT } & \multicolumn{3}{|c|}{ SANTOS } & \multicolumn{3}{|c|}{ Resultados acumulados } \\
\hline & positivo & negativo & Total & positivo & negativo & Total & positivo & negativo & Total & positivo & negativo & Total & positivo & negativo & Total \\
\hline & \multicolumn{15}{|c|}{ Cotilédone } \\
\hline positivo & 27 & 0 & 27 & 27 & 0 & 27 & 27 & 0 & 27 & 24 & 3 & 27 & 105 & 3 & 108 \\
\hline negativo & 6 & 21 & 27 & 2 & 25 & 27 & 7 & 20 & 27 & 1 & 26 & 27 & 16 & 92 & 108 \\
\hline \multirow[t]{2}{*}{ Total } & 33 & 21 & 54 & 29 & 25 & 54 & 34 & 20 & 54 & 25 & 29 & 54 & 121 & 95 & 216 \\
\hline & \multicolumn{15}{|c|}{ Linfonodo supramamário } \\
\hline positivo & 10 & 2 & 12 & 7 & 5 & 12 & 8 & 4 & 12 & 11 & 1 & 12 & 36 & 12 & 48 \\
\hline negativo & 2 & 25 & 27 & 2 & 25 & 27 & 2 & 25 & 27 & 1 & 26 & 27 & 7 & 101 & 108 \\
\hline \multirow[t]{2}{*}{ Total } & 12 & 27 & 39 & 9 & 30 & 39 & 10 & 29 & 39 & 12 & 27 & 39 & 43 & 113 & 156 \\
\hline & \multicolumn{15}{|c|}{ Linfonodo pré-escapular } \\
\hline positivo & 10 & 7 & 17 & 7 & 10 & 17 & 8 & 9 & 17 & 15 & 2 & 17 & 40 & 28 & 68 \\
\hline negativo & 2 & 25 & 27 & 5 & 22 & 27 & 5 & 22 & 27 & 1 & 26 & 27 & 13 & 95 & 108 \\
\hline \multirow[t]{2}{*}{ Total } & 12 & 32 & 44 & 12 & 32 & 44 & 13 & 31 & 44 & 16 & 28 & 44 & 53 & 123 & 176 \\
\hline & \multicolumn{15}{|c|}{ Fígado } \\
\hline positivo & 5 & 1 & 6 & 3 & 3 & 6 & 4 & 2 & 6 & 6 & 0 & 6 & 18 & 6 & 24 \\
\hline negativo & 0 & 27 & 27 & 3 & 24 & 27 & 2 & 25 & 27 & 0 & 27 & 27 & 5 & 103 & 108 \\
\hline \multirow[t]{2}{*}{ Total } & 5 & 28 & 33 & 6 & 27 & 33 & 6 & 27 & 33 & 6 & 27 & 33 & 23 & 109 & 132 \\
\hline & \multicolumn{15}{|c|}{ Baço } \\
\hline positivo & 3 & 7 & 10 & 3 & 7 & 10 & 4 & 6 & 10 & 7 & 3 & 10 & 17 & 23 & 40 \\
\hline negativo & 1 & 26 & 27 & 2 & 25 & 27 & 2 & 25 & 27 & 2 & 25 & 27 & 7 & 101 & 108 \\
\hline \multirow[t]{2}{*}{ Total } & 4 & 33 & 37 & 5 & 32 & 37 & 6 & 31 & 37 & 9 & 28 & 37 & 24 & 124 & 148 \\
\hline & \multicolumn{15}{|c|}{ Úbere } \\
\hline positivo & 7 & 0 & 7 & 4 & 3 & 7 & 6 & 1 & 7 & 5 & 2 & 7 & 22 & 6 & 28 \\
\hline negativo & 8 & 19 & 27 & 1 & 26 & 27 & 5 & 22 & 27 & 0 & 27 & 27 & 14 & 94 & 108 \\
\hline \multirow[t]{2}{*}{ Total } & 15 & 19 & 34 & 5 & 29 & 34 & 11 & 23 & 34 & 5 & 29 & 34 & 36 & 100 & 136 \\
\hline & \multicolumn{15}{|c|}{ Resultados acumulados } \\
\hline positivo & 62 & 17 & 79 & 51 & 28 & 79 & 57 & 22 & 79 & 68 & 11 & 79 & 238 & 78 & 316 \\
\hline negativo & 19 & 143 & 162 & 15 & 147 & 162 & 23 & 139 & 162 & 5 & 157 & 162 & 62 & 586 & 648 \\
\hline Total & 81 & 160 & 241 & 66 & 175 & 241 & 80 & 161 & 241 & 73 & 168 & 241 & 300 & 664 & 964 \\
\hline
\end{tabular}

Pos: positivo; Neg: negativo.

Os resultados acumulados para os métodos de extração de DNA, constantes da tabela 3, mostraram que o protocolo de Santos apresentou maior sensibilidade relativa do que o de Boom ( $p=0,003)$ ou o GT $(p=0,0506)$ e igual ao PK $(p=0,2969)$. As demais comparações de proporções não resultaram em diferenças estatisticamente significantes. Na mesma tabela, os resultados acumulados por órgãos mostraram que a sensibilidade relativa foi superior no cotilédone do que no linfonodo supramamário $(\mathrm{p}=0,0001)$, linfonodo pré-escapular 
$(p<0,0001)$, fígado $(p=0,0006)$, baço $(p<0,0001)$ ou úbere $(p=0,0019)$. A verificada no baço foi inferior à do fígado $(\mathrm{p}=0,0233)$, úbere $(\mathrm{p}=0,0067)$ ou linfonodo supramamário $(\mathrm{p}=0,0039)$. As demais comparações de proporções não resultaram em diferenças estatisticamente significantes.

Tabela 4 - Sensibilidade relativa (Sr) para protocolos de extração de DNA utilizados na detecção de Brucella abortus pela PCR em órgãos de vacas experimentalmente infectadas com a cepa 2308, considerando o isolamento pela bacteriologia clássica como gold standard - São Paulo - 2009

\begin{tabular}{|c|c|c|c|c|c|c|c|c|c|c|}
\hline \multirow{3}{*}{$\begin{array}{l}\text { Resultado do isolamento nos } \\
\text { órgãos }\end{array}$} & \multicolumn{10}{|c|}{ Resultados da PCR segundo os protocolos de extração de DNA } \\
\hline & \multicolumn{2}{|c|}{ PK } & \multicolumn{2}{|c|}{ BOOM } & \multicolumn{2}{|c|}{ GT } & \multicolumn{2}{|c|}{ SANTOS } & \multicolumn{2}{|c|}{ Resultados acumulados } \\
\hline & $\mathrm{Sr}(\%)$ & $\mathrm{ICI} 195 \%(\%)$ & $\operatorname{Sr}(\%)$ & $\mathrm{ICI} 95 \%(\%)$ & $\operatorname{Sr}(\%)$ & $\mathrm{ICl} 95 \%(\%)$ & $\operatorname{Sr}(\%)$ & $\mathrm{ICl} 95 \%(\%)$ & $\operatorname{Sr}(\%)$ & $\mathrm{ICl} 195 \%(\%)$ \\
\hline Cotilédone & 100 & {$[84,5 ; 100]$} & 100 & {$[84,5 ; 100]$} & 100 & {$[84,5 ; 100]$} & 89 & {$[69,7 ; 97,1]$} & 97 & {$[91,5 ; 99,3]$} \\
\hline Linfonodo supramamário & 83 & {$[50,1 ; 97,0]$} & 58 & {$[28,6 ; 83,5]$} & 67 & {$[35,4 ; 88,7]$} & 92 & {$[59,7 ; 99,6]$} & 75 & {$[60,1 ; 85,9]$} \\
\hline Linfonodo pré-escapular & 50 & {$[33,4 ; 80,6]$} & 41 & {$[19,4 ; 66,5]$} & 47 & {$[23,8 ; 71,5]$} & 88 & {$[62,2 ; 97,9]$} & 59 & {$[46,2 ; 70,4]$} \\
\hline Fígado & 83 & {$[36,5 ; 99,1]$} & 50 & {$[13,9 ; 86,0]$} & 67 & {$[24,1 ; 94,0]$} & 100 & {$[51,7 ; 100]$} & 75 & {$[52,9 ; 89,4]$} \\
\hline Baço & 30 & {$[8,1 ; 64,6]$} & 30 & {$[8,1 ; 64,6]$} & 40 & {$[13,7 ; 72,6]$} & 70 & {$[35,4 ; 91,9]$} & 57 & {$[41,0 ; 72,6]$} \\
\hline Úbere & 100 & {$[56,1 ; 100]$} & 57 & {$[20,2 ; 88,2]$} & 86 & {$[42,0 ; 99,2]$} & 71 & {$[30,2 ; 94,9]$} & 79 & {$[58,5 ; 91,0]$} \\
\hline Resultados acumulados & 78 & {$[67,5 ; 86,6]$} & 64 & {$[52,9 ; 74,8]$} & 72 & {$[60,7 ; 81,4]$} & 86 & {$[76,0 ; 92,5]$} & 75 & {$[70,1 ; 79,9]$} \\
\hline
\end{tabular}

Todas as vacas selecionadas para o experimento integraram teste clínico de vacina contra brucelose, portanto foram desafiadas com a cepa 2308 de B. abortus. Assim, considerando a infecção experimental como gold standard, foram elaboradas as tabelas 5 e 6 . A tabela 5 traz os resultados das PCR para os quatro protocolos de extração de DNA estudados e a tabela 6 apresenta os valores de sensibilidade relativa verificados. 
Tabela 5 - Resultados dos protocolos de extração de DNA para detecção de Brucella abortus pela PCR em órgãos de vacas infectadas experimentalmente com a cepa 2308 - São Paulo - 2009

\begin{tabular}{|c|c|c|c|c|c|}
\hline \multirow{2}{*}{ Resultados da PCR por órgão } & \multicolumn{5}{|c|}{ Protocolos de extração de DNA } \\
\hline & PK & BOOM & GT & SANTOS & Resultados acumulados \\
\hline & \multicolumn{5}{|c|}{ Cotilédone } \\
\hline PCR positivo & 33 & 29 & 34 & 25 & 121 \\
\hline PCR negativo & 21 & 25 & 20 & 29 & 95 \\
\hline \multirow[t]{2}{*}{ Total } & 54 & 54 & 54 & 54 & 216 \\
\hline & \multicolumn{5}{|c|}{ Linfonodo supramamário } \\
\hline PCR positivo & 12 & 9 & 10 & 12 & 43 \\
\hline PCR negativo & 27 & 30 & 29 & 27 & 113 \\
\hline \multirow[t]{2}{*}{ Total } & 39 & 39 & 39 & 39 & 156 \\
\hline & \multicolumn{5}{|c|}{ Úbere } \\
\hline PCR positivo & 15 & 5 & 11 & 5 & 36 \\
\hline PCR negativo & 19 & 29 & 23 & 29 & 100 \\
\hline \multirow[t]{2}{*}{ Total } & 34 & 34 & 34 & 34 & 136 \\
\hline & \multicolumn{5}{|c|}{ Linfonodo pré-escapular } \\
\hline PCR positivo & 12 & 12 & 13 & 16 & 53 \\
\hline PCR negativo & 32 & 32 & 31 & 28 & 123 \\
\hline \multirow[t]{2}{*}{ Total } & 44 & 44 & 44 & 44 & 176 \\
\hline & \multicolumn{5}{|c|}{ Fígado } \\
\hline PCR positivo & 5 & 6 & 6 & 6 & 23 \\
\hline PCR negativo & 28 & 27 & 27 & 27 & 109 \\
\hline \multirow[t]{2}{*}{ Total } & 33 & 33 & 33 & 33 & 132 \\
\hline & \multicolumn{5}{|c|}{ Baço } \\
\hline PCR positivo & 4 & 5 & 6 & 9 & 24 \\
\hline PCR negativo & 33 & 32 & 31 & 28 & 124 \\
\hline \multirow[t]{2}{*}{ Total } & 37 & 37 & 37 & 37 & 148 \\
\hline & \multicolumn{5}{|c|}{ Resultados acumulados } \\
\hline Total PCR positivo & 81 & 66 & 80 & 73 & \\
\hline Total PCR negativo & 160 & 175 & 161 & 168 & \\
\hline Total geral & 241 & 241 & 241 & 241 & \\
\hline
\end{tabular}

Os resultados acumulados para os métodos de extração de DNA, constantes da tabela 5, mostraram não haver diferenças estatisticamente significantes entre as suas sensibilidades relativas. Na mesma tabela, os resultados acumulados por órgãos mostraram que a sensibilidade relativa foi superior no cotilédone do que no linfonodo supramamário ( $p=<0,0001)$, linfonodo pré-escapular $(p<0,0001)$, fígado $(p=<0,0001)$, baço $(p<0,0001)$ ou úbere $(\mathrm{p}=<0,0001)$. A verificada no baço foi inferior à do linfonodo supramamário $(\mathrm{p}=0,02)$, linfonodo pré-escapular $(\mathrm{p}=0,005)$ ou úbere $(\mathrm{p}=0,05)$. A verificada no fígado foi inferior à do linfonodo supramamário $(\mathrm{p}=0,04)$ e linfonodo pré-escapular $(\mathrm{p}=0,01)$. As demais comparações de proporções não resultaram em diferenças estatisticamente significantes. 
Tabela 6 - Sensibilidade relativa (Sr) para protocolos de extração de DNA utilizados na deteç̧ão de Brucella abortus pela PCR em órgãos de vacas experimentalmente infectadas com a cepa 2308 - São Paulo 2009

\begin{tabular}{|c|c|c|c|c|c|c|c|c|c|c|}
\hline \multirow{3}{*}{ Órgãos } & \multicolumn{10}{|c|}{ Protocolos de extração de DNA } \\
\hline & \multicolumn{2}{|r|}{ PK } & \multicolumn{2}{|c|}{ BOOM } & \multicolumn{2}{|c|}{ GT } & \multicolumn{2}{|c|}{ SANTOS } & \multicolumn{2}{|c|}{ Resultados acumulados } \\
\hline & $\mathrm{Sr}(\%)$ & $\mathrm{Cl} 95 \%(\%)$ & $\mathrm{Sr}(\%)$ & $\mathrm{Cl} 195 \%(\%)$ & $\mathrm{Sr}(\%)$ & $\mathrm{Cl} 95 \%(\%)$ & $\mathrm{Sr}(\%)$ & $\mathrm{Cl} 195 \%(\%)$ & $\mathrm{Sr}(\%)$ & $\mathrm{Cl} 195 \%(\%)$ \\
\hline Cotilédone & 61 & {$[46,9 ; 73,8]$} & 54 & {$[39,7 ; 67,1]$} & 63 & {$[48,7 ; 75,4]$} & 46 & {$[32,8 ; 60,3]$} & 56 & {$[49,1 ; 62,7]$} \\
\hline Linfonodo supramamário & 31 & {$[17,5 ; 47,7]$} & 23 & {$[11,7 ; 39,7]$} & 26 & {$[13,6 ; 42,4]$} & 31 & {$[17,5 ; 47,7]$} & 27 & {$[20,9 ; 35,4]$} \\
\hline Linfonodo pré-escapular & 27 & {$[15,4 ; 43,0]$} & 27 & {$[15,4 ; 43,0]$} & 29 & {$[17,2 ; 45,4]$} & 36 & {$[22,8 ; 52,2]$} & 30 & {$[23,5 ; 37,5]$} \\
\hline Fígado & 15 & {$[5,7 ; 32,6]$} & 18 & {$[7,6 ; 36,1]$} & 18 & {$[7,6 ; 36,1]$} & 18 & {$[7,6 ; 36,1]$} & 17 & {$[11,6 ; 25,2]$} \\
\hline Baço & 11 & {$[3,5 ; 26,3]$} & 13 & {$[5,1 ; 29,6]$} & 16 & {$[6,8 ; 32,7]$} & 24 & {$[12,4 ; 41,5]$} & 16 & {$[10,9 ; 23,4]$} \\
\hline Úbere & 44 & {$[27,6 ; 61,9]$} & 15 & {$[5,5 ; 31,8]$} & 32 & {$[18,0 ; 50,6]$} & 15 & {$[5,5 ; 31,8]$} & 26 & {$[19,4 ; 34,8]$} \\
\hline Resultados acumulados & 34 & {$[27,7 ; 40,0]$} & 27 & {$[21,9 ; 33,5]$} & 33 & {$[27,3 ; 39,6]$} & 30 & {$[24,6 ; 36,6]$} & & \\
\hline
\end{tabular}

Os resultados da detecção de Brucella abortus pelo isolamento clássico e PCR realizada com quatro diferentes protocolos de extração de DNA em amostras de cotilédone, linfonodo supramamário, úbere, linfonodo pré-escapular, fígado, e baço de vacas infectadas experimentalmente com a cepa 2308 , podem ser observados nas tabelas $7,8,9,10,11$, e 12 , respectivamente apresentadas em apêndices.

As figuras 1, 2, 3 e 4 mostram os resultados da amplificação da PCR para os diferentes protocolos de extração de DNA testados.

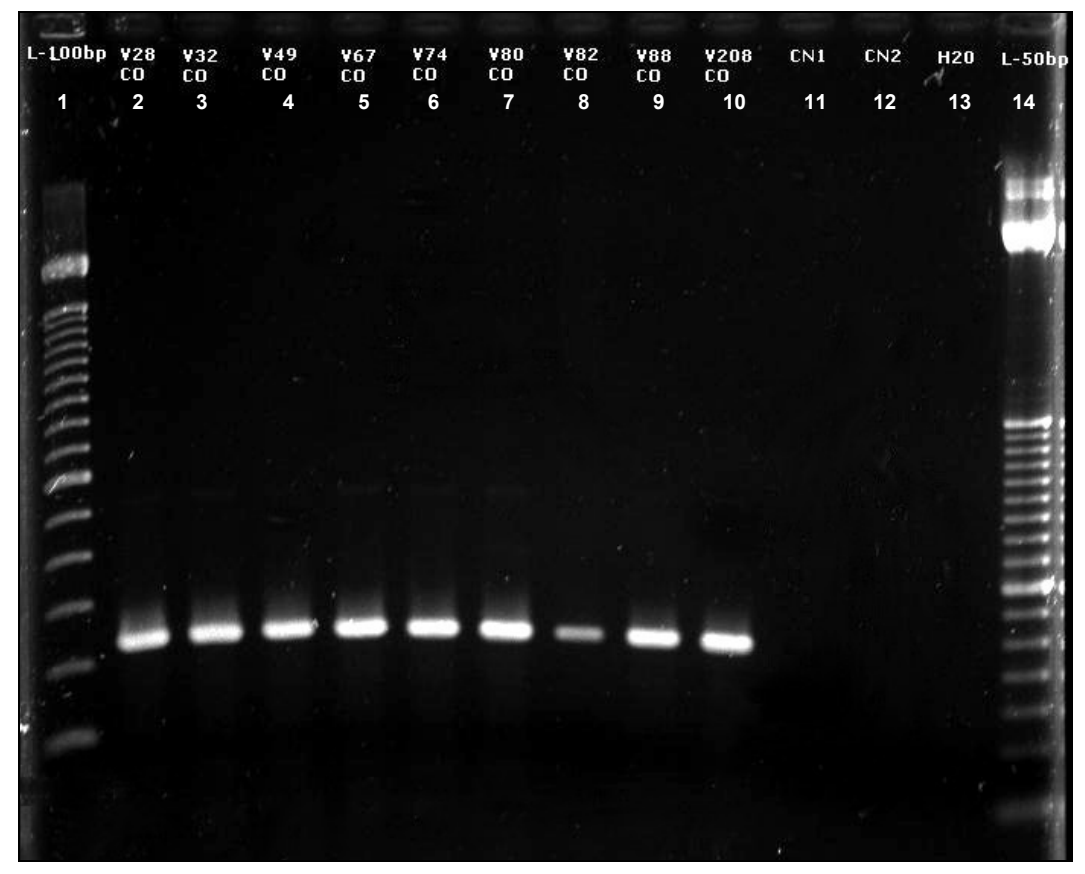

Figura 1 - Gel de agarose mostrando fragmento de $223 \mathrm{pb}$ amplificado pela PCR em amostras de cotilédone de vacas experimentalmente infectadas com Brucella abortus 2308, utilizando extração enzimática do DNA por Proteinase K, onde: (1) padrão de peso molecular, $100 \mathrm{pb}$; (2-10) amostra de cotilédone; (11-12) controles negativos; (14) padrão de peso molecular, 50 pb - São Paulo - 2009 


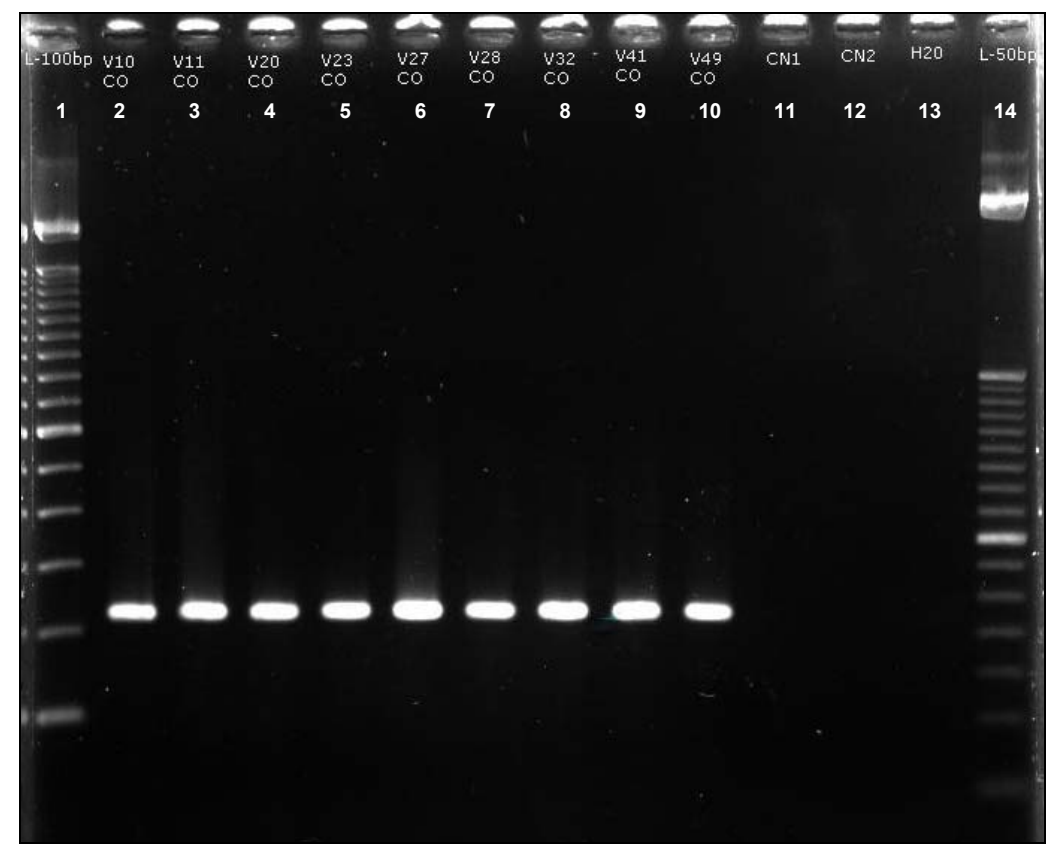

Figura 2 - Gel de agarose mostrando fragmento de $223 \mathrm{pb}$ amplificado pela PCR em amostras de cotilédone de vacas experimentalmente infectadas com Brucella abortus 2308, utilizando extração enzimática do DNA pelo método adaptado de Boom, onde: (1) padrão de peso molecular, $100 \mathrm{pb}$; (2-10) amostra de cotilédone; (11-12) controles negativos; (14) padrão de peso molecular, $50 \mathrm{pb}$ São Paulo - 2009

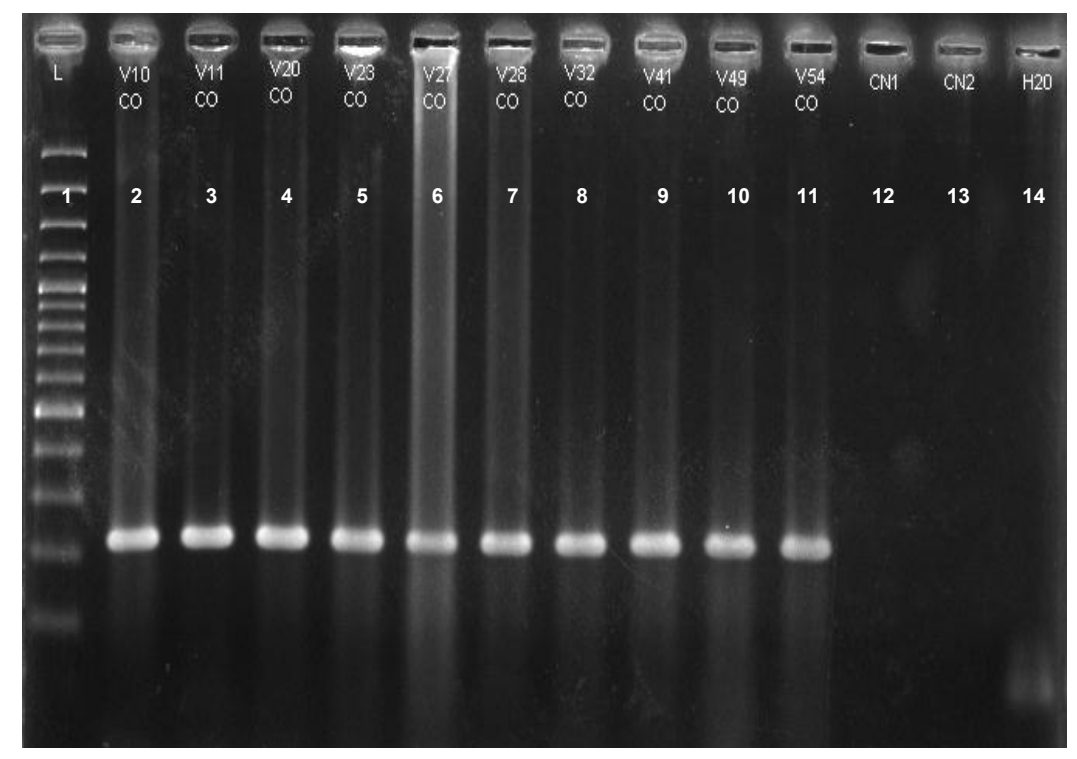

Figura 3 - Gel de agarose mostrando fragmento de $223 \mathrm{pb}$ amplificado pela PCR em amostras de cotilédone de vacas experimentalmente infectadas com Brucella abortus 2308, utilizando extração enzimática do DNA pelo Isotiocianato de Guanidina - GT, onde: (1) padrão de peso molecular, 100 pb; (2-10) amostra de cotilédone; (11-12) controles negativos; (14) água - São Paulo - 2009 


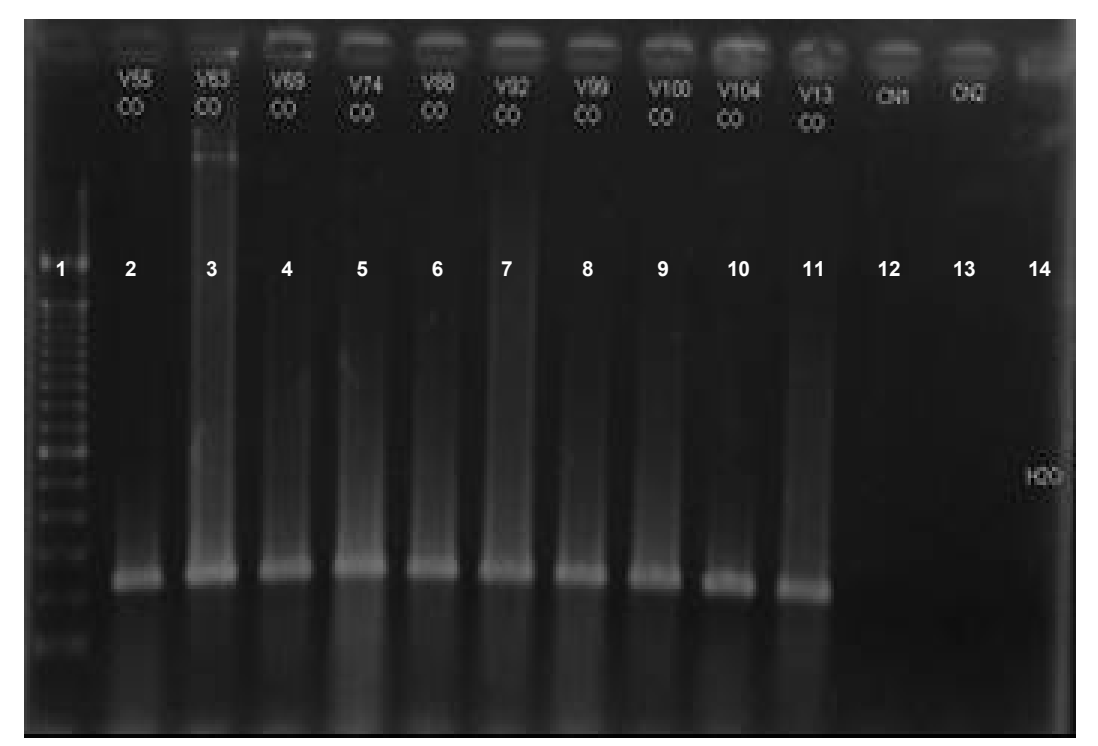

Figura 4 - Gel de agarose mostrando fragmento de $223 \mathrm{pb}$ amplificado pela PCR em amostras de cotilédone de vacas experimentalmente infectadas com Brucella abortus 2308, utilizando extração enzimática do DNA pelo método adaptado de Santos, onde: (1) padrão de peso molecular, $100 \mathrm{pb}$; (2-10) amostra de cotilédone; (11-12) controles negativos; (14) água - São Paulo - 2009 


\section{DISCUSSÃO}

Em relação aos ensaios com cultura pura, o protocolo GT apresentou o melhor limiar de detecção (1,5 x $10^{-2}$ bactérias $\left./ \mathrm{mL}\right)$, seguido pelos protocolos PK, Boom e Santos, empatados com um limiar de detecção de $1,5 \times 10^{3}$ bactérias/mL (Tabela 2). O protocolo de GT detectou uma fração de 0,015 da bactéria o que é incoerente. Isso provavelmente ocorreu em função da baixa precisão da quantificação bacteriana pela escala de McFarland. Além disso, é razoável supor que existam UFC produzidas por mais de uma bactéria. Em resumo, a escala de McFarland e as contagens de UFC podem ter sub-quantificado o número de bacilos em suspensão.

Considerando a bacteriologia clássica como gold standard, o método de extração de Santos apresentou melhor sensibilidade relativa (86\%) que os métodos de GT (72\%) e Boom (64\%), porém não apresentou diferença estatística significante com relação ao método PK (78\%) (Tabela 3).

O protocolo de Santos tem sido utilizado para a extração de DNA de Mycobacterium leprae a partir de pele, pêlos sobre lesões cutâneas e secreção nasal (Comunicação pessoal) ${ }^{1}$. Tem como vantagem a simplicidade e o baixo custo, mas como desvantagem a necessidade de se utilizar nitrogênio líquido, elemento de difícil manipulação em laboratório. Havia sido testado por Ribeiro (2006) para detectação de Mycobacterium bovis a partir de lesões tuberculosas de bovinos, porém sem grande sucesso.

$\mathrm{O}$ protocolo de extração $\mathrm{PK}$ já havia sido estudado por vários autores. Fekete et al. (1990) verificaram que a esse protocolo foi eficiente para a detecção de B. abortus em fígado pela PCR. Cortez (1999) também reportou a eficácia desse protocolo para a extração de DNA de B. abortus. Richtzenhain et al. (2002) encontraram uma sensibilidade de $100 \%$ na detecção de Brucella spp pela PCR, utilizando o método de PK para extração de DNA a partir homogeneizados de órgãos de fetos abortados. Leal-Klevezas et al. (1995) empregaram com êxito o método de extração de PK para detecção de $B$. abortus em sangue de bovinos infectados. Considerando a infecção experimental como gold standard, não houve diferença estatisticamente significante entre os protocolos de extração estudados (Tabelas 5 e 6).

\footnotetext{
${ }^{1}$ Informação fornecida por SANTOS em Rio de Janeiro, 2003.
} 
A baixa sensibilidade do método Boom pode ter sido conseqüência da permanência de resquícios da suspensão carreadora (Diatomaceous earth) na etapa final da extração, fazendo com que o DNA ficasse aderido a ela, impedindo sua eluição.

O desempenho do protocolo GT pode ter sido prejudicado pela presença de grande quantidade de fatores inibidores da amplificação do ácido nucléico, como proteínas séricas, debris de células somáticas, polissacarídeos e outros componentes dos fluidos corpóreos (WILSON, 1997), ou grande quantidade de DNA do hospedeiro, pois esse método não inclui pré-lavagem das amostras, procedimento realizado no método de extração PK e numa fase intermediária do protocolo Boom. Morata et al. (1998) demonstram que o aumento do número de lavagens nas amostras pode suprimir os inibidores da amplificação do DNA. Neste estudo pode se concluir que a pré-lavagem não foi uma variável importante para o protocolo de Santos.

Importante ressaltar que das 79 amostras que apresentaram resultado positivo para o cultivo, algumas resultaram negativas para a PCR: 11 com DNA extraído pelo protocolo Santos, 17 pelo PK, 22 pelo GT e 28 pelo Boom (Tabela 3). Todos os protocolos de extração apresentaram resultados positivos à $\mathrm{PCR}$ em amostras que resultaram negativas ao isolamento: 5 para o Santos, 15 para o Boom, 19 para o PK e 23 para o GT. Cortez et al. (2001), detectaram quatro amostras positivas para a PCR em 54 amostras classificadas como negativas pela bacteriologia clássica. Fekete et al. (1990) obtiveram dois positivos para a PCR em 52 negativas ao isolamento.

A especificidade da PCR não foi calculada para os protocolos de extração de DNA, pois depende apenas do gene e da seqüência dos primers escolhidos (FEKETE et al., 1990). Neste estudo foram usados os primers B4 e B5 descritos por Baily et al. (1992) para detecção de Brucella abortus e Brucella melitensis. Estes primers mostraram bons resultados e uma boa especificidade, não apresentando homologia de seqüências com outras bactérias (BAILY et al., 1992) e foram utilizados com sucesso em vários estudos (MATAR et al., 1996; QUEIPOORTUÑO et al., 1997; CORTEZ, 1999; CORTEZ et al., 2001; ZERVA et al., 2001; RICHTZENHAIN et al., 2002). Mostraram inespecificidade apenas frente à infecção humana por Ochrobactrum spp. (CIESLAK et al., 1992; CASANAS et al., 2001).

Assim, os melhores métodos de extração de DNA para detecção de B. abortus a partir de tecidos de vacas infectadas foram Santos e PK.

O cotilédone mostrou-se o melhor órgão para detecção de Brucella abortus pela PCR em homogeneizado de órgãos de vacas infectadas experimentalmente com Brucella abortus 2308 , que teve como resultado uma sensibilidade relativa acumulada de $97 \%$ (100\% para os 
protocolos PK, GT e Boom e 89\% para o Santos (Tabela 4). Este resultado pode ser explicado pelo fato da Brucella abortus ter sua multiplicação estimulada pelo eritritol, poli-álcool encontrado no útero gravídico (CARTER; CHENGAPPA, 1991). Alexender et al. (1981) verificaram que um grama de cotilédone de vaca infectada pela $B$. abortus contém $1,4 \times 10^{13}$ brucelas. Esta alta quantidade bacteriana explica porque o cotilédone se mostra como o órgão de predileção para a detecção de Brucella abortus, lembrando que a sensibilidade da PCR depende da quantidade de DNA do agente presente na amostra (FEKETE et al., 1990).

O baço apresentou a menor sensibilidade relativa acumulada (57\%, Tabela 4), estatisticamente inferior a todos os demais órgãos, exceto o linfonodo pré-escapular. O baço requereu muitas lavagens, pois a grande quantidade de sangue nele contida pode inibir a detecção da Brucella. A hemoglobina e derivados do grupo "hem" podem atuar como inibidores da amplificação de DNA (NAVARRO et al., 1999). Some-se a isso a baixa quantidade de $B$. abortus na fase de crecimento presente no baço de vacas infectadas Bosseray et al. ${ }^{1}$ (1983 apud SAMARTINO; ENRIGHT, 1993, p. 97).

O linfonodo supramamário (75\%) e úbere $(79 \%)$ tiveram maior sensibilidade relativa acumulada do que o baço (Tabela 4). Esses bons resultados são conseqüência da presença de eritritol nos tecidos mamários, potente estimulador do crescimento da B. abortus (CARTER; CHENGAPPA, 1991). Esses resultados são corroborados por vários autores: Bishop et al. ${ }^{2}$ (1984 apud PAULIN e FERREIRA NETO, 2003, p. 60) reportaram que isola-se B. abortus em linfonodos supramamários de ate 90\% dos animais infectados; Leal-Klevezas et al. (1995) mencionaram que a $B$. abortus está localizada nos linfonodos supramamários em até $80 \%$ dos animais infectados; Seonádh et al. (2006) concluíram que é possível isolar Brucella abortus dos linfonodos.

Resultados semelhantes foram observados quando o gold standard passou a ser a infecção experimental (Tabelas 5 e 6), exceto para o linfonodo pré-escapular e fígado. Nesse critério, o baço e o fígado passaram a ser os piores órgãos para a detecção de $B$. abortus pela PCR. Os comentários feitos para o baço, em relação à grande quantidade de sangue, podem também valer para o fígado.

\footnotetext{
${ }^{1}$ BOSSERAY, N. Kinetics of placental colonization of mice inoculated intravenously with Brucella abortus at15 of pregnancy. Br. J. Exp. Pathol, v. 64, p.12- 216, 1983.

${ }^{2}$ BISHOP, G. C.; BOSMAN, P. P.; HERR, S. Bovine brucellosis. In: COETZER, J. A. N.; THOMSON, G. R.; TUSTIN, R. C. (Ed.). Infectious diseases of livestock, Austin: Texas AeM University Press, College Station, 1994. v.2, p.1053-1066.
} 
Assim, em relação aos órgãos ou estruturas testados, o cotilédone é o mais indicado para a detecção de $B$. abortus em vacas infectadas, seguido por um conjunto de órgãos composto por linfonodos supramamário, pré-escapular e úbere e, como piores, o fígado e o baço.

Considerando os resultados obtidos, as maiores proporções de resultados positivos para a detecção de $B$. abortus pela PCR foram alcançadas nos cotilédones, utilizando-se os protocolos de extração Santos ou PK.

Assim, apesar das desvantagens do método bacteriológico clássico, a melhor estratégia para o diagnóstico direto da infecção de vacas por B. abortus em homogeneizado de órgãos é a utilização conjunta do isolamento e da PCR, examinando os cotilédones e utilizando os métodos de extração de DNA Santos ou PK. 


\section{CONCLUSÕES}

> A sensibilidade da PCR para detecção de Brucella abortus em tecidos de vacas infectadas é influenciada pelo método de extração de DNA empregado.

Os protocolos de extração de Santos e PK foram os mais sensíveis.

$>$ O cotilédone mostrou ser o melhor órgão para detecção de Brucella abortus pela PCR quando comparada ao linfonodo supramamário, linfonodo pré-escapular, fígado, baço e úbere. 


\section{REFERÊNCIAS}

ACHA, P. N.; SZYFRES, B. Zoonosis y enfermedades transmisibles comunes al hombre y a los animales. 3. ed. Washington: O.P.S., 2001. p. 28-55.

ADAMS, L. G. Development of lives Brucella vaccines. In ADAMS, L.G. (Ed.). Advances in Brucellosis research. Austin: Texas A\&M University Press, College Station, 1990. p. 251276.

ALEXENDER, B.; SCHNURRENBERGER, P. R.; BROWN, R. R. Number of Brucella abortus in the placenta, umbilicus and fetal fluid of two naturally infected cows. The Veterinary Record, v. 108, p. 500. 1981.

ALTON, G. G.; JONES, L. M.; PIETZ, D.E. Laboratory techniques in brucellosis. World Health Organization. 2.ed., Geneva, 1975. 175 p.

ALTON, G. G.; JONES, L. M.; ANGUS, R. D.; VERGER, J. M. Techniques for the brucellosis laboratory. Paris: Institut National de la Recherche Agronomique, 1988. 545 p.

BAILY, G. G.; KRAHN, J. B.; DRASAR, B. S.; SOKER, N. G. Detection of Brucella melitensis and Brucella abortus by DNA amplification. Journal of Tropical Medicine and Hygiene, v. 95, p. 271-275, 1992.

BATHKE, W. Brucellosis. In: BEER, J. (Ed.). Doenças infecciosas em animais domésticos: doenças causadas por vírus, clamídias, ricketticiose, micoplasmose. Roca: São Paulo, 1988. v. 2, p. 144-160.

BISHOP, G. C.; BOSMAN, P. P.; HERR, S. Bovine brucellosis. In: COETZER, J. A. N.; THOMSON, G. R.; TUSTIN, R. C. (Ed.). Infectious diseases of livestock, Austin: Texas AeM University Press, College Station, 1994. v.2, p.1053-1066.

BOOM, R.; SOL, C. J. A.; SALIMANS, M. M. M.; JANSEN, C. L.; WERTHEIM-VAN DILLEN, P. M.E.; VAN DER NOORDAA, J. Rapid and simple method for purification of nucleic acids. Journal of Clinical Microbiology, v. 28, n. 3, p. 495-503, 1990.

BRASIL, Ministério da Agricultura, Pecuária e Abastecimento (MAPA). Planos e Programas. Programas. Área Animal. Programa Nacional de Controle e Erradicação da Brucelose e da Tuberculose (PNCEBT). Instrução Normativa do Serviço Nacional Animal número 6, de oito de janeiro de 2004. Regulamento PNCEBT. Disponível em:

$<$ http://www.agricultura.gov.br $>$. Acesso em: 1 mar. 2009.

BREW, S. D.; PERRETT, L. L.; STACK, J. A.; MACMILLAN, A. P.; STANTON, N. J. Human exposure to Brucella recovered from a sea mammal. The Veterinary Record, v. 144, p. 483, 1999.

BRICKER, B. J.; HALLING, S. Differentiation of Brucella abortus bv. 1, 2, and 4, Brucella melitensis, Brucella ovis, and Brucella suis bv. 1 by PCR. Journal of Clinical Microbiology, v. 32, n. 11, p. 2660-2666, 1994.

BRICKER, B. J. PCR as a diagnostic tool for brucellosis. Veterinary Microbiology, v. 90, p. 435-446, 2002. 
BRICKER, B. J.; EWALT, D. R.; OLSEN, S. C.; JENSEN, A. E. Evaluation of the Brucella abortus species-specific polymerase chain reaction assay, an improved version of the Brucella AMOS polymerase chain reaction assay for cattle. Journal of Veterinary Diagnostic Investigation, v, 15, p. 374-378, 2003.

BRICKER, B. J. Molecular diagnostics of animal brucellosis: a review of PCR-Based assays and approaches. In: LÓPEZ-GOÑI, I.; MORIYÓN, I. (Ed.). Brucella - molecular and cellular biology. Norfolk: Horizon Bioscience, 2004.

BRICKER, B. J.; EWALT, D. Evaluation of the HOOF-Print assay for typing Brucella abortus strains isolated from cattle in the United States: results with four performance criteria. BMC Microbiology, v. 5, n. 37, p.1-13, 2005.

CARTER, G. R.; CHENGAPPA, M. M. Brucella. In: CARTER, G. R.; CHENGAPPA, M. M. (Ed.). Essentials of veterinary bacteriology and mycology. 4. ed. Philadelphia: London, 1991, p.196- 200.

CASANAS, M. C.; QUEIPO-ORTUNO, M. I.; RODRIGUEZ-TORRES, A.; ORDUNA, A.; COLMENERO, J. D.; MORATA, P. Specificity of a polymerase chain reaction assay of a target sequence on the 31 Kilodalton Brucella antigen DNA used to diagnose human brucellosis. European Journal Clinical Microbiology Infectious Diseases, v. 20, n. 2, p. 127-131, 2001.

ÇETINKAYA, B.; ONGOR, H.; MUZ, A.; ERTAS, H. B.; KALENDER, H.; ERDOGAN, H. M. Detection of Brucella species DNA in the Stomach Content of Aborted Sheep Fetuses by PCR. The Veterinary Record, v. 144, p. 239-240, 1999.

CHOMKZYNSKI, P. A. Reagent for the single step simultaneous isolation of RNA, DNA and proteins from cells and tissue samples. Biotechniques, v. 15, p. 532-537, 1993.

CHU, M. C.; WEYANT, R. S. Francisella and Brucella. In: MURRAY, P. R.; BARON, E. J.; JORGENSON, J. H.; PFALLER, M. A.; YOLKEN, R. H. Manual of Clinical Microbiology. 8. ed. Washington: ASM Press, 2003, p. 789-804.

CIESLAK, T. J.; ROBB, M. L.; DRABICK, C. J.; FISCHER, G. W. Catheter-associated sepsis caused by Ochrobactrum anthropi: report of a case and review of related nonfermentative bacteria. Clinical Infectious Diseases, v. 14, n. 4, p. 902-907, 1992.

CLOECKAERT, A.; VERGER, J. M. ; GRAYON, M.; AND GRÉPINET, O. Restriction site polymorphism of the genes encoding the major $25 \mathrm{kDa}$ and $36 \mathrm{kDa}$ outer-membrane proteins of Brucella. Microbiology, v. 141, p. 2111-2121, 1995.

CLOECKAERT, A.; VERGER, J.; GRAYON, M.; PAQUET, J.; GARIN-BASTUJI, B.; FOSTER, G.; GODFROID, J. Classification of Brucella spp. isolated from marine mammals by DNA polymorphism at the omp2 locus. Microbes and Infection, v. 3, p. 729-738, 2001.

CLOECKAERT, A.; VIZCAÍNO, N.; PAQUET, J.; BOWDEN, R.; ELZER, P. Major outer membrane proteins of Brucella spp.: past, present and future. Veterinary Microbiology, $v$. 90, p. 229-247, 2002.

CLOECKAERT, A.; GRAYON, M.; GREPINET, O.; BOUMEDINE, K. S. Classification of Brucella strains isolated from marine mammals by infrequent restriction site-PCR and 
development of specific PCR identification tests. Microbes and Infection, v. 5, n. 7, p. 593$602,2003$.

CLOECKAERT, A.; VIZCAÍNO, N. DNA polymorphism and taxonomy of Brucella species. In: LÓPEZ-GOÑI, I.; MORYÓN, I. (Ed.). Brucella: molecular and celullar biology. 1. ed. England: Horizon Bioscience, 2004, p. 1-23.

COLMENERO, J. D.; QUEIPO-ORTUÑO, M. I.; MORATA, P. Polymerase chain reaction: a powerful new approach for the diagnosis of human brucellossis. In: I. López-Goñi e I.

Moriyón (Ed.). Brucella - molecular and cellular biology. Norfolk: Horizon Bioscience, 2004. $423 \mathrm{p}$.

CORBEL, M. J. Recent advances in the study of Brucella antigens and their serological crossreactions. Veterinary Bulletin, December, v. 55, n. 12. p. 927-942, 1985.

CORBEL, M. J. Brucellosis: an overview. Emergency Infectious Diseases, v. 3, p. 213-221, 1997.

CORBEL, M. J.; ELBERG, S. S.; COSIVI, O. (Ed.). Brucellosis in humans and animals. Geneva: WHO Press, 2006. 89 p.

CORTEZ, A. Detecção de DNA de Brucella spp. em amostras clínicas de abortos bovinos pela reação em cadeia pela polimerase. 1999. 34 f. Dissertação (Mestrado em Medicina Veterinária) - Faculdade de Medicina Veterinária e Zootecnia, Universidade de São Paulo, São Paulo, 1999.

CORTEZ, A.; SCARCELLI, E.; SOARES, R. M.; HEINEMANN, M. B.; SAKAMOTO, S. M.; GENOVEZ, M. E.; FERREIRA, F.; RICHTZENHAIM, L. J. Detection of Brucella DNA from aborted bovine foetuses by polymerase chain reaction. Australian Veterinary Journal, v. 79, n. 7, p. 500-501, 2001.

DA COSTA, M. In: Doenças de Rumiantes e Equinos. RIET-CORREA, F.; SCHILD, A.L.; MÉNDEZ, M.; LEMOS, R. (Eds). Edit. Varela. Vol 1, 2da reimpressão. 2006, p.187-197.

DAHOUK, S. A.; TOMASO, H.; NOCKLER K.; NEUBAUER H.; FRANGOULIDIS D. Laboratory based diagnosis of brucellosis- A review of the literature. Clinical Laboratory, v. 49, p. 487-505, 2003.

DIEFFENBACH, C.W.; DRAGON, E.A.; DVEKSLER, G. S. Setting up a PCR laboratory. In: PCR primer: a laboratory manual. New York: Cold Spring, Harbor Laboratory Press, 1995. p. 7-16.

EWALT, D.; BRICKER, J. Validation of the Abbreviated Brucella AMOS PCR as a Rapid Screening Method for Differentiation of Brucella abortus Field Strain Isolates and the Vaccine Strains, 19 and RB51. Journal of Clinical Microbiology, v. 38, n. 8, p. 3085-3086, 2000.

EWALT, D. R.; BRICKER, B. J. Identification and differentiation of Brucella abortus field and vaccine strains by BaSS-PCR. Methods in Molecular Biology, v. 216, p. 97-108, 2003.

FEKETE, A.; BANTLE, J. A.; HALLING, S. M.; SANBORN, M. R. Preliminary

Development of a Diagnostic Test for Brucella using Polymerase Chain Reaction. Journal of Applied Bacteriology, v. 69, p. 216-227, 1990. 
FEKETE, A.; BANTLE, J. A.; HALLING, S. M. Detection of Brucella by polymerase chain reaction in bovine fetal and maternal tissues. Journal of Veterinary Investigation, v. 4, p. 79-83, 1992.

FICHT, T.A.; BEARDEN, S.W.; SOWA, B.A.; MARQUIS, H. Genetic variation at the omp2 porin locus of the brucellae: species-specific markers. Molecular Microbiology, v. 4, p. $1135-1142,1990$.

FOSTER, G.; OSTERMAN, B. S.; GODFROID, J.; JACQUES, I.; CLOECKAERT, A. Brucella ceti $\mathrm{sp}$. nov. and Brucella pinnipedialis sp. nov. for Brucella strains with cetaceans and seals as their preferred hosts. International Journal of Systematic Evolutionary Microbiology, v. 57, p. 2688-2693, 2007.

GALLIEN, P.; DORN, C.; ALBAN, G.; STAAK, C.; PROTZ, D. Detection of Brucella species in organs of naturally infected cattle by polymerase chain reaction. Veterinary Record, v. 142, p. 512-514, 1998.

GARIN-BASTUJI, B.; BLASCO, J. M.; MARÍN, C.; ALBERT, D. The diagnosis of brucellosis in sheep and goats, old and new tools. Small Ruminant Research, v. 62, p. 63 70. 2006.

HALLING, S. M.; TATUM, F. M.; BRICKER, B. J. Sequence and characterization of an insertion sequence IS711 from B. ovis. Gene, v. 133, p. 123-127, 1993.

HUBALEK, Z.; SCHOLZ, H. C.; SEDLÁCEK, I.; MELZER, F.; SANOGO, Y.; NESVADBOVA, J. Brucellosis of the common vole (Microtus arvalis). Vector Borne Zoonotic Diseases, v. 7, p. 679-688, 2007.

INPPAZ. Reunión Grupo de Trabajo sobre Prevención, Control y Erradicación de la Brucelosis en América Latina y el Caribe. Programa de Salud Pública Veterinaria. Falta local: OMS, 1994. Documento de Trabajo. Instituto Panamericano de Protección de alimentos e zoonosis (INPPAZ).

JAWETZ, E.; MELNICK, J.L.; ADELBERG, E.A. Microbiologia médica. Rio de Janeiro:. Guanabara Koogan, 1984. 568 p.

LAGE, A. P.; ROXO, E.; MÜLLER, E.; POESTER, F.; CAVALLÉRO, J. C. M.; FERREIRA NETO, J. S.; MOTA, P. M. P. C.; GONÇALVES, V. S. P. Programa nacional de controle e erradicação da brucelose e da tuberculose animal (PNCEBT). 1. ed. Brasília: Ministério da Agricultura, Pecuária e Abastecimento, 2006. 188 p. (Manual Técnico).

LEAL-KLEVEZAS, D. S.; MARTINEZ-VAZQUEZ, I. O.; LOPEZ-MERINO, L.; MARTINEZ-SORIANO, J. P. Single-stpe PCR for detection of Brucella spp. from blood and milk of infected animals. Journal Clinical Microbiology, v. 12, p. 3087-3090, 1995.

LEYLA, G.; KADRI, G.; UMRAN, O. Comparison of polymerase chain reaction and bacteriological cultura for the diagnosis of sheep brucellosis using aborted fetus samples. Veterinary Microbiology, v. 93, p. 53-61, 2003.

LÓPEZ-GOÑI, I.; MORIYÓN, I. Brucella molecular and cellular biology. Wymondham, England: Horizon Bioscience. 1ed, 2004. 432 p. 
MATAR, G. M.; KHNEISSER, I. A.; ABDELNOOR, A. M. Rapid laboratory confirmation of human brucellosis by PCR analysis of a target sequence on the 31 kilodalton Brucella antigen DNA. Journal of Veterinary Microbiology, v. 34, n. 2, p. 477-478, 1996.

MCDONALD, W. L.; JAMALUDIN, R.; MACKERETH, G.; HANSEN, M.; HUMPHREY, S.; SHORT, P.; TAYLOR, T.; SWINGLER, J.; DAWSON, C. E.; WHATMORE, A. M.; STUBBERFIELD, E.; PERRETT, L. L.; SIMMONS, G. Characterization of a Brucella sp. strain as a marine-mammal type despite isolation from a patient with spinal osteomyelitis in New Zealand. Journal of Clinical Microbiology, v. 44, p. 4363-4370, 2006.

METCALF, H. E.; LUCHSINGER, D. W.; RAY, W. C. Brucellosis. In: BERAN, G. W.; STEELE, J. H. (Ed.). Handbook series in zoonoses. Section A: bacterial, rickettsial, chlamydial, and mycotic. 2. ed. Boca Raton: CRC Press, 1994. p. 9-39.

MORATA, P.; QUEIPO-ORTUÑO, M. I.; COLMENERO, J. D. Strategy for optimizing DNA amplification in a peripheral blood pcr assay used for diagnosis of human Brucellosis. Journal of Clinical Microbiology, v. 36, n. 9, p. 2443-2446, 1998.

MULLIS, K. B.; FALOONA, F. A. Specific synthesis of DNA in vitro via a polymerasecatalyzed chain reaction. Methods in Enzymology, v. 155, p. 335-350, 1987.

NAVARRO, E.; FERNANDEZ, J.A.; SOLERA, J. PCR Assay for Diagnosis of Human Brucellosis. Journal of Clinical Microbiology, p. 1654-1655, 1999.

NEWBY, D.; HADFIELD, T.; ROBERTO, F. Real-Time PCR Detection of Brucella abortus: a comparative study of sybr green I,5' - Exonuclease, and hybridization probe assays. Applied and Environmental Microbiology, v. 69, n. 8, p. 4753-4759, 2003.

NIELSEN, K. Diagnosis of Brucellosis by serology. Veterinary Microbiology, n. 90, p. 447459, 2002.

OCAMPO-SOSA, A.; AGUERO-BALBÍN, J.; GARCÍA-LOBO, J. Development of a new PCR assay to identify Brucella abortus biovars 5, 6 and 9 and the new subgroup $3 \mathrm{~b}$ of biovar 3. Veterinary Microbiology, v. 110, p. 41-51, 2005.

OIE. Organização internacional de epizootia. Bovine Brucellosis. Manual of Diagnostic Tests and Vaccines for Terrestrial Animals, 2004. Pt. 2, sec. 2.3, chap. 2.3.1. Disponível em: $<$ http://www.oie.int/esp/normes/mmanual/A_00052.htm>. Acceso em: 1 mar. 2009.

OIE. ORGANIZAÇÃO INTERNACIONAL DE EPIZOOTIA. Bovine Brucellosis. Article 2.3.1. Terrestrial Animal Health code 2006. Pt. 2, chap. 2.3.1. Disponível em: $<$ http://www.oie.int $>$. Acesso em: 28 jun. 2008.

OMS. ORGANIZACIÓN MUNDIAL DE LA SALUD. Comité Mixto FAO/OMS de expertos en Brucelosis. Ginebra: Graficas Reunidas, 1986. 149 p. (Série de informes técnicos, 740).

OSTERMAN, B.; MORIYÓN, I. Minutes of the meeting, 17 September 2003, Pamplona, Spain International. Committee on Systematics of Prokaryotes; Subcommittee on the taxonomy of Brucella. Internacional of Journal of Systematic and Evolutionary Microbiology, v. 56, p. 1173-1175, 2006. 
OUAHRANI, S.; MICHAUX, S.; SRI WIDADA, J.; BOURG, G.; TOURNEBIZE, R.; RAMUZ, M.; AND LIAUTARD, J. P. Identification and sequence analysis of IS6501 an insertion sequence in Brucella spp: relationship between genomic structure and the number of IS6501 copies. Journal of General Microbiology, v. 139, p. 3265-3273, 1993.

PADILLA, C. R.; MONTOYA, Y. P.; CARRILLO, C. P. Estandarización de una prueba de PCR para la detección de Brucella sp. Revista Peruana de Medicina Experimental y Salud Pública, v. 20, n. 2, p.102-104, 2003

PAULIN, L. M.; FERREIRA NETO, J. S. O Combate à brucelose bovina. Situação brasileira. Jaboticabal: Funep. 2003. 121 p.

POESTER, F. P.; GONÇALVES, V. S. P.; LAGE, A. P. Brucellosis in Brazil. Veterinary Microbiology, v. 90, n. 1-4, p. 55-62, 2002.

PROBERT, W.; SCHRADERr, K.; KHUONG, N.; BYSTROM, S.; GRAVES, M. Real-Time Multiplex PCR Assay for Detection of Brucella spp., B. abortus, and B. melitensis. Journal of Clinical Microbiology, v. 42, n. 3, p. 1290-1293, 2004.

QUEIPO-ORTUÑO, M. I.; MORATA, P.; OCÓN, P.; MANCHADO, P.; COLMENERO J. D. Rapid diagnosis of human brucellosis by peripheral-blood pcr assay. Journal of Clinical Microbiology, v. 35, n. 11, p. 2927-2930. 1997.

QUINN, P. J.; CARTER, M. E.; MARKEY, B.; CARTER, G. R. Clinical veterinary microbiology. Londom: Wolfe Publishing, 1994, 648 p.

RANTAKOKKO-JALAVA, K.; JALAVA, J. Optimal DNA isolation method for detection of bacteria in clinical specimens by broad-range PCR. Journal of Clinical Microbiology, v. 40, n. 11, p. 4211-4217, 2002.

REDKAR, R.; ROSE, S.; BRICKER, B.; DELVECCHIO, V. Real-Time detection of Brucella abortus, Brucella melitensis and Brucella suis. Molecular and Cellular Probes, v. 15, p. 43$52,2001$.

RIBEIRO, D. C. Comparação de protocolos de extração de DNA para detecção de Mycobacterium bovis através da PCR em homogeneizado de órgãos. 2006. $55 \mathrm{f}$. Dissertação (Mestrado em Medicina Veterinária) - Faculdade de Medicina Veterinária e Zootecnia, Universidade de São Paulo, São Paulo, 2006.

RICHTZENHAIN, L. J.; CORTEZ, A.; HEINEMANN, M. B.; SOARES, R. M.; SAKAMOTO, S. M.; VASCONCELLOS, S. A.; HIGA, Z. M. M.; SCARCELLI, E.; GENOVEZ, M. E. A multiplex PCR for the detection of Brucella spp. and Leptospira spp. DNA from aborted bovine fetuses. Veterinary Microbiology, v. 87, p. 139-147, 2002.

RIEMANN, H. P.; CLIVER, D. Foodborne infections and intoxications. Amsterdam, Boston: Elsevier Academic Press. 2006. 903 p.

RIJPENS, N.; JANNES, G.; ASBROECK, M.; ROSSAU, R.; HERMAN. L. Direct Detection of Brucella spp. In Raw Milk by PCR and Reverse Hybridization with 16S-23S rRNA Spacer Probes. Applied and Environmental Microbiology, v. 62, n. 5, p. 1683-1688, 1996. 
ROMERO, C.; GAMAZO, C.; PARDO, M.; LÓPEZ-GONI, I. Specific detection of Brucella DNA by PCR. Journal of Clinical Microbiology, v. 33, n. 3, p. 615-617, 1995.

ROUX, J. Brucella. In: LE MINOR, L.; VEROM, M. (Ed.). Bactériologie médicale. Paris: Flamarion, 1989, p.651-670.

SAGDR. SECRETARIA DE AGRICULTURA, GANADERÍA Y DESARROLLO RURAL. Manual de actualización técnica para la aprobación del médico veterinario en tuberculosis bovina y brucelosis. Palo Alto. 1995.99 p.

SAMARTINO, L. E.; ENRIGHT, F. M. Pathogenesis of abortion of bovine brucellosis. Comparative Immunology, Microbiology and Infectious Diseases, v. 16, n. 2, p. 95-101, 1993.

SAMBROOK, J.; FRITSCH, E. F.; MANIATIS, T. Molecular cloning: a laboratory manual. 2. ed. Cold Spring Harbor: Cold Spring Harbor Laboratory Press, 1989.

SANTOS, A. R.; GOES FILHO, J. T.; NERY, J. A. C.; DUPPRE, N. C.; GALLO, M. E. N; SUFFYS, P. N.; DEGRAVE, W. M. Evaluation of PCR mediated DNA amplification in noninvasive biological specimens for subclinical detection of Mycobacterium leprae. FEMS Immunology and Medical Microbiology, v. 11, p. 113-120, 1995.

SCHOLZ, H.C.; HUBALEK, Z.; SEDLÁCEK, I.; VERGNAUD, G.; TOMASO, H.; AL DAHOUK, S.; MELZER, F.; KÄMPFER, P.; NEUBAUER, H.; CLOECKAERT, A.; MAQUART M, Z. Y.; GMUNT, M. S.; WHATMORE, A. M.; FALSEN, E.; BAHN, P.; GÖLLNER, C.; PFEFFER, M.; HUBER, B.; BUSSE, H. J.; NÖCKLER, K. Brucella microti sp. nov., isolated from the common vole Microtus arvalis. International Journal of Systematic and evolutionary microbioology, v. 58, p.375-82, 2008.

SCHURIG, G. G. Vacinas contra brucelose: passado, presente e future. In Anniversary of Brucellosis Research Conference, 50, 1997, Chicago. p. 8-9.

SCHURIG, G. G.; SRIRANGANATHAN, N.; CORBEL, M. J. Brucellosis vaccines: past, present and future. Veterinary Microbiology, v. 90, p. 479-496, 2002.

SEÓNADH, O. L.; MICHAEL, S.; TORRES, S. Brucella abortus detection by PCR assay in blood, milk and lymph tissue of serologically positive cows. Research in Veterinary Science, v. 81, p. 170-176, 2006.

SOHN, A. H.; PROBERT, W. S.; GIASER, C. A.; GUPTA, N.; BOLLEN, A. W.; WONG, J. D.; GRACE, E. M.; McDONALD, W. C. Human neurobrucellosis with intracerebral granuloma caused by a marine mammal Brucella spp. Emerging Infectious Diseases, v. 9, p. 485-488, 2003.

SREEVATSAN, S.; BOOKOUT, J.; RINGPIS, F.; PERUMAALLA, V.; FICHT, T.; ADAMS, G.; HAGIUS, S.; ELZER, P.; BRICKER, B.; KUMAR, G.; RAJASEKHAR, M.; ISLOOR, S.; BARATHUR, R. A Multiples Approach to Molecular Detection of Brucella abortus and/or Mycobacterium bovis Infection in Cattle. Journal of Clinical Microbiology, v. 38, n. 7, p. 2602-2610. 2000. 
TIMONEY, J. F.; GILLESPIE, J. H.; SCOTT, F. W.; BARLOUGH, J. E. Hagan and Bruner's microbiology and infectious diseases of domestic animals. London: Comstock Publishing Associates. Division of Cornell University Press, 1988. p. 135-144.

TIZARD, I. R. Veterinary immunology. An introduction. Philadelphia: W.B. Saunders, 1996.

VERSTREATE, D. R.; CREASY, M. T.; CAVENEY, N. T.; BALDWIN, C. L.; BLAB, M. W.; WINTER, A. J. Outer membrane proteins of Brucella abortus: isolation and characterization. Infection and Immunity, v. 35, p. 979-989, 1982.

VIZCAÍNO, N.; CLOECKAERT, A.; VERGER, J.; GRAVON, M.; FERNÁNDEZ-LAGO, L. DNA polymorphism in the genus Brucella. Microbes and Infection, v. 2, n. 9, p. 1089$1100,2000$.

WALKER, R. L. Brucella. In: Microbiologia veterinária. HIRSH, D. C.; ZEE, Y. C. (Ed.). Rio de Janeiro: Guanabara-Koogan. 2003. p.185-191.

WILSON, I.G. Inhibition and facilitation of nucleic acid amplification. Applied and Enviromental Microbiology, v.63, n. 10, p. 3741-3751, 1997.

ZERVA, L.; BOURANTAS, K.; MITKA, S.; KANSOUZIDOU, A.; LEGAKIS, N. J. Serum is the preferred clinical specimen for diagnosis of human brucellosis by PCR. Journal of Clinical Microbiology, v. 39, n. 4, p. 1661-1664, 2001. 
APÊNDICES 
APÊNDICE A - Tabela 7- Resultados da detecção de Brucella abortus pelo isolamento clássico e pela PCR realizada com quatro diferentes protocolos de extração de DNA em amostras de cotilédone de vacas experimentalmente infectadas como a cepa 2308 - São Paulo 2009

\begin{tabular}{|c|c|c|c|c|c|}
\hline \multirow{2}{*}{ Número da amostra } & \multirow{2}{*}{$\begin{array}{c}\text { Isolamento } \\
\text { Brucella abortus }\end{array}$} & \multicolumn{4}{|c|}{ Protocolos de extração de DNA } \\
\hline & & PK & BOOM & GT & SANTOS \\
\hline V10 & + & + & + & + & + \\
\hline $\mathrm{V} 11$ & + & + & + & + & + \\
\hline V20 & + & + & + & + & + \\
\hline V23 & + & + & + & + & + \\
\hline V27 & + & + & + & + & + \\
\hline V28 & + & + & + & + & + \\
\hline V32 & + & + & + & + & + \\
\hline V41 & + & + & + & + & + \\
\hline V49 & + & + & + & + & + \\
\hline V54 & + & + & + & + & + \\
\hline V55 & + & + & + & + & + \\
\hline V63 & + & + & + & + & + \\
\hline V69 & + & + & + & + & + \\
\hline V74 & + & + & + & + & + \\
\hline V88 & + & + & + & + & + \\
\hline V92 & + & + & + & + & + \\
\hline V99 & + & + & + & + & + \\
\hline V100 & + & + & + & + & + \\
\hline V104 & + & + & + & + & + \\
\hline V13 & + & + & + & + & + \\
\hline V67 & + & + & + & + & + \\
\hline V80 & + & + & + & + & + \\
\hline V208 & + & + & + & + & + \\
\hline V228 & + & + & + & + & + \\
\hline V82 & + & + & + & + & - \\
\hline V205 & + & + & + & + & - \\
\hline V234 & + & + & + & + & - \\
\hline V48 & - & + & - & + & - \\
\hline V204 & - & + & - & - & + \\
\hline V22 & - & + & - & - & - \\
\hline V219 & - & + & - & - & - \\
\hline V223 & - & + & - & - & - \\
\hline V29 & - & + & - & - & - \\
\hline V224 & - & - & + & + & - \\
\hline V03 & - & - & + & - & - \\
\hline V226 & - & - & - & + & - \\
\hline V227 & - & - & - & + & - \\
\hline V52 & - & - & - & + & - \\
\hline V59 & - & - & - & + & - \\
\hline V231 & - & - & - & + & - \\
\hline V206 & - & - & - & - & - \\
\hline V225 & - & - & - & - & - \\
\hline V42 & - & - & - & - & - \\
\hline V232 & - & - & - & - & - \\
\hline $\mathrm{V} 12$ & - & - & - & - & - \\
\hline V66 & - & - & - & - & - \\
\hline V73 & - & - & - & - & - \\
\hline V76 & - & - & - & - & - \\
\hline V202 & - & - & - & - & - \\
\hline V207 & - & - & - & - & - \\
\hline V209 & - & - & - & - & - \\
\hline V212 & - & - & - & - & - \\
\hline V215 & - & - & - & - & - \\
\hline V203 & - & - & - & - & - \\
\hline Total & $27 / 54$ & $33 / 54$ & $29 / 54$ & $34 / 54$ & $25 / 34$ \\
\hline
\end{tabular}


APÊNDICE B - Tabela 8- Resultados da deteç̧ão de Brucella abortus pelo isolamento clássico e pela PCR realizada com quatro diferentes protocolos de extração de DNA em amostras de linfonodo supramamário de vacas experimentalmente infectadas como a cepa 2308 - São Paulo - 2009

\begin{tabular}{|c|c|c|c|c|c|}
\hline \multirow{2}{*}{ Número da amostra } & \multirow{2}{*}{$\begin{array}{c}\text { Isolamento Brucella } \\
\text { abortus }\end{array}$} & \multicolumn{4}{|c|}{ Protocolos de extração de DNA } \\
\hline & & PK & BOOM & GT & SANTOS \\
\hline V10 & + & + & + & + & + \\
\hline V41 & + & + & + & + & + \\
\hline V54 & + & + & + & + & + \\
\hline V55 & + & + & + & + & + \\
\hline V74 & + & + & + & + & + \\
\hline V104 & + & + & + & - & + \\
\hline V20 & + & + & - & + & + \\
\hline V23 & + & + & - & + & + \\
\hline V103 & + & + & - & - & + \\
\hline V40 & + & + & - & + & - \\
\hline V228 & + & - & + & - & + \\
\hline V18 & + & - & - & - & + \\
\hline V48 & - & + & - & - & - \\
\hline V215 & - & + & - & - & - \\
\hline V226 & - & - & + & - & - \\
\hline V12 & - & - & + & - & - \\
\hline V224 & - & - & - & + & - \\
\hline V231 & - & - & - & + & - \\
\hline V223 & - & - & - & - & + \\
\hline V03 & - & - & - & - & - \\
\hline V22 & - & - & - & - & - \\
\hline V204 & - & - & - & - & - \\
\hline V206 & - & - & - & - & - \\
\hline V219 & - & - & - & - & - \\
\hline V227 & - & - & - & - & - \\
\hline V232 & - & - & - & - & - \\
\hline V29 & - & - & - & - & - \\
\hline V42 & - & - & - & - & - \\
\hline V52 & - & - & - & - & - \\
\hline V59 & - & - & - & - & - \\
\hline V66 & - & - & - & - & - \\
\hline V73 & - & - & - & - & - \\
\hline V76 & - & - & - & - & - \\
\hline V202 & - & - & - & - & - \\
\hline V207 & - & - & - & - & - \\
\hline V209 & - & - & - & - & - \\
\hline V212 & - & - & - & - & - \\
\hline V225 & - & - & - & - & - \\
\hline V203 & - & - & - & - & - \\
\hline Total & $12 / 39$ & $12 / 39$ & $9 / 39$ & $10 / 39$ & $12 / 39$ \\
\hline
\end{tabular}


APÊNDICE C - Tabela 9- Resultados da detecção de Brucella abortus pelo isolamento clássico e pela PCR realizada com quatro diferentes protocolos de extração de DNA em amostras de linfonodo pré-escapular de vacas experimentalmente infectadas como a cepa 2308 São Paulo - 2009

\begin{tabular}{|c|c|c|c|c|c|}
\hline \multirow{2}{*}{ Número da amostra } & \multirow{2}{*}{$\begin{array}{c}\text { Isolamento Brucella } \\
\text { abortus }\end{array}$} & \multicolumn{4}{|c|}{ Protocolos de extração de DNA } \\
\hline & & PK & BOOM & GT & SANTOS \\
\hline V20 & + & + & + & + & + \\
\hline V41 & + & + & + & + & + \\
\hline V63 & + & + & + & + & + \\
\hline V99 & + & + & + & + & + \\
\hline V67 & + & + & + & + & + \\
\hline V104 & + & + & + & + & - \\
\hline V54 & + & + & + & - & + \\
\hline V14 & + & + & - & - & + \\
\hline V217 & + & + & - & - & + \\
\hline V208 & + & + & - & - & + \\
\hline V218 & + & - & - & + & + \\
\hline V228 & + & - & - & + & - \\
\hline V216 & + & - & - & - & + \\
\hline V7 & + & - & - & - & + \\
\hline V18 & + & - & - & - & + \\
\hline V43 & + & - & - & - & + \\
\hline V86 & + & - & - & - & + \\
\hline V219 & - & + & + & - & - \\
\hline V227 & - & - & + & - & + \\
\hline V48 & - & + & - & - & - \\
\hline V204 & - & - & + & - & - \\
\hline V206 & - & - & + & - & - \\
\hline V66 & - & - & + & - & - \\
\hline V03 & - & - & - & + & - \\
\hline V22 & - & - & - & + & - \\
\hline V207 & - & - & - & + & - \\
\hline V212 & - & - & - & + & - \\
\hline V225 & - & - & - & + & - \\
\hline V223 & - & - & - & - & - \\
\hline V226 & - & - & - & - & - \\
\hline V232 & - & - & - & - & - \\
\hline V12 & - & - & - & - & - \\
\hline V29 & - & - & - & - & - \\
\hline V42 & - & - & - & - & - \\
\hline V52 & - & - & - & - & - \\
\hline V59 & - & - & - & - & - \\
\hline V73 & - & - & - & - & - \\
\hline V76 & - & - & - & - & - \\
\hline V202 & - & - & - & - & - \\
\hline V209 & - & - & - & - & - \\
\hline V224 & - & - & - & - & - \\
\hline V231 & - & - & - & - & - \\
\hline V215 & - & - & - & - & - \\
\hline V203 & - & - & - & - & - \\
\hline Total & $17 / 44$ & $12 / 44$ & $12 / 44$ & $13 / 44$ & $16 / 44$ \\
\hline
\end{tabular}


APÊNDICE D - Tabela 10- Resultados da detecção de Brucella abortus pelo isolamento clássico e pela PCR realizada com quatro diferentes protocolos de extração de DNA em amostras de fígado de vacas experimentalmente infectadas como a cepa 2308 - São Paulo - 2009

\begin{tabular}{lccccc}
\hline \multirow{2}{*}{ Número da amostra } & $\begin{array}{c}\text { Isolamento Brucella } \\
\text { abortus }\end{array}$ & \multicolumn{4}{c}{ Protocolos de extração de DNA } \\
\cline { 2 - 6 } V69 & + & PK & BOOM & GT & SANTOS \\
\hline V74 & + & + & + & + & + \\
V80 & + & + & + & + & + \\
V23 & + & + & + & - & + \\
V208 & + & + & - & + & + \\
V104 & + & + & - & - & + \\
V73 & - & - & - & + & + \\
V231 & - & - & + & - & - \\
V203 & - & - & + & - & - \\
V223 & - & - & + & - & - \\
V232 & - & - & - & + & - \\
V03 & - & - & - & + & - \\
V22 & - & - & - & - & - \\
V48 & - & - & - & - & - \\
V204 & - & - & - & - & - \\
V206 & - & - & - & - & - \\
V219 & - & - & - & - & - \\
V226 & - & - & - & - & - \\
V227 & - & - & - & - & - \\
V12 & - & - & - & - & - \\
V29 & - & - & - & - & - \\
V42 & - & - & - & - & - \\
V52 & - & - & - & - & - \\
V59 & - & - & - & - & - \\
V66 & - & - & - & - & - \\
V76 & - & - & - & - & - \\
V202 & - & - & - & - & - \\
V207 & - & - & - & - & - \\
V209 & - & - & - & - & - \\
V212 & - & - & - & - & - \\
V224 & - & - & - & - & - \\
V225 & - & - & - & - & - \\
V215 & - & - & - & - & - \\
Total & - & -333 & - & - \\
\hline & & - & - & - & - \\
\hline
\end{tabular}


APÊNDICE E - Tabela 11- Resultados da detecção de Brucella abortus pelo isolamento clássico e pela PCR realizada com quatro diferentes protocolos de extração de DNA em amostras de baço de vacas experimentalmente infectadas como a cepa 2308 - São Paulo - 2009

\begin{tabular}{|c|c|c|c|c|c|}
\hline \multirow{2}{*}{ Número da amostra } & \multirow{2}{*}{$\begin{array}{c}\text { Isolamento Brucella } \\
\text { abortus }\end{array}$} & \multicolumn{4}{|c|}{ Protocolos de extração de DNA } \\
\hline & & PK & BOOM & $\mathbf{G T}$ & SANTOS \\
\hline V74 & + & + & + & + & + \\
\hline V208 & + & + & + & + & - \\
\hline V41 & + & + & - & + & - \\
\hline V13 & + & - & + & - & + \\
\hline V14 & + & - & - & + & + \\
\hline V217 & + & - & - & - & + \\
\hline V30 & + & - & - & - & + \\
\hline V43 & + & - & - & - & + \\
\hline V86 & + & - & - & - & + \\
\hline V104 & + & - & - & - & - \\
\hline V202 & - & + & + & - & - \\
\hline V203 & - & - & + & - & - \\
\hline V76 & - & - & - & + & - \\
\hline V207 & - & - & - & + & - \\
\hline V212 & - & - & - & - & + \\
\hline V225 & - & - & - & - & + \\
\hline V03 & - & - & - & - & - \\
\hline V22 & - & - & - & - & - \\
\hline V48 & - & - & - & - & - \\
\hline V204 & - & - & - & - & - \\
\hline V206 & - & - & - & - & - \\
\hline V219 & - & - & - & - & - \\
\hline V223 & - & - & - & - & - \\
\hline V226 & - & - & - & - & - \\
\hline V227 & - & - & - & - & - \\
\hline V232 & - & - & - & - & - \\
\hline V12 & - & - & - & - & - \\
\hline V29 & - & - & - & - & - \\
\hline V42 & - & - & - & - & - \\
\hline V52 & - & - & - & - & - \\
\hline V59 & - & - & - & - & - \\
\hline V66 & - & - & - & - & - \\
\hline V73 & - & - & - & - & - \\
\hline V209 & - & - & - & - & - \\
\hline V224 & - & - & - & - & - \\
\hline V231 & - & - & - & - & - \\
\hline V215 & - & - & - & - & - \\
\hline Total & $10 / 37$ & $4 / 37$ & $5 / 37$ & $6 / 37$ & $9 / 37$ \\
\hline
\end{tabular}


APÊNDICE F - Tabela 12- Resultados da detecção de Brucella abortus pelo isolamento clássico e pela PCR realizada com quatro diferentes protocolos de extração de DNA em amostras de úbere de vacas experimentalmente infectadas como a cepa 2308 - São Paulo - 2009

\begin{tabular}{cccccc}
\hline \multirow{2}{*}{ Número da amostra } & $\begin{array}{c}\text { Isolamento Brucella } \\
\text { abortus }\end{array}$ & \multicolumn{4}{c}{ Protocolos de extração de DNA } \\
\cline { 2 - 6 } V63 & + & PK & BOOM & GT & SANTOS \\
\hline V74 & + & + & + & + & + \\
V23 & + & + & + & + & + \\
V10 & + & + & + & + & + \\
V32 & + & + & - & + & - \\
V99 & + & + & - & + & + \\
V216 & + & + & - & - & - \\
V206 & - & + & - & + & - \\
V224 & - & - & + & + & - \\
V03 & - & + & - & - & - \\
V22 & - & + & - & - & - \\
V48 & - & + & - & - & - \\
V204 & - & + & - & - & - \\
V219 & - & + & - & - & - \\
V223 & - & + & - & - & - \\
V232 & - & + & - & - & - \\
V29 & - & - & - & + & - \\
V73 & - & - & - & + & - \\
V225 & - & - & - & + & - \\
V226 & - & - & - & - & - \\
V227 & - & - & - & - & - \\
V12 & - & - & - & - & - \\
V42 & - & - & - & - & - \\
V52 & - & - & - & - & - \\
V59 & - & - & - & - & - \\
V66 & - & - & - & - & - \\
V76 & - & - & - & - \\
V202 & - & - & - & - \\
V207 & - & - & - & - \\
V209 & - & - & - & - \\
V212 & - & - & - & - \\
V231 & - & - & - & - \\
V215 & - & - & - & - \\
V203 & - & - & - & - \\
Total & & - & - & - & - \\
\hline & & - & - & - & - \\
\hline
\end{tabular}

